University of Nebraska - Lincoln

DigitalCommons@University of Nebraska - Lincoln

Keys to Adults of All Genera and Larvae of 19 Species of Gymnetini (Coleoptera: Scarabaeidae: Cetoninae) in the New World, with a Species Checklist and Descriptions of Two New Genera and Species from Mexico and Mertinique

Brett C. Ratcliffe

University of Nebraska-Lincoln, bratcliffe1@unl.edu

Follow this and additional works at: https://digitalcommons.unl.edu/entomologyfacpub

Part of the Entomology Commons

Ratcliffe, Brett C., "Keys to Adults of All Genera and Larvae of 19 Species of Gymnetini (Coleoptera: Scarabaeidae: Cetoninae) in the New World, with a Species Checklist and Descriptions of Two New Genera and Species from Mexico and Mertinique" (2019). Faculty Publications: Department of Entomology. 810.

https://digitalcommons.unl.edu/entomologyfacpub/810

This Article is brought to you for free and open access by the Entomology, Department of at DigitalCommons@University of Nebraska - Lincoln. It has been accepted for inclusion in Faculty Publications: Department of Entomology by an authorized administrator of DigitalCommons@University of Nebraska - Lincoln. 


\title{
Keys to Adults of All Genera and Larvae of 19 Species of Gymnetini (Coleoptera: Scarabaeidae: Cetonitnae) in the New World, with a Species Checklist and Descriptions of Two New Genera and Species from Mexico and Martinique
}

\author{
BRetT C. RatClifFe \\ Systematics Research Collections, University of Nebraska State Museum \\ W-436 Nebraska Hall, University of Nebraska \\ Lincoln, NE 68588-0514, USA \\ bratcliffe1@unl.edu
}

\begin{abstract}
Keys to adults of all 27 genera and larvae of 19 species in 10 genera of Gymnetini that occur in the New World are presented. Supplementing the key to adults is a checklist of all species, their synonyms, and all literature citations associated with the nomenclatural epithets. Two new genera, Gymnephoria Ratcliffe and Madiana Ratcliffe and Romé, with one new species each, are described from Mexico and Martinique, respectively.
\end{abstract}

Key Words: flower chafers, taxonomy, new species, identification, nomenclature, synonyms

DOI.org/10.1649/0010-065X-73.1.1

Zoobank.org/urn:lsid:zoobank.org:pub:DABCC591-6424-4546-A8D0-32B5DE6B69AA

Our generation is the first to fully appreciate the threats facing millions of species, and the last generation with the opportunity to explore, describe and classify life on Earth so completely. Species that are literally ours for the taking will soon be inaccessible to science at any cost. What we accomplish in taxonomic work in this century will be a priceless legacy to all the generations of scientists, natural historians and educated humans that follow.

\section{— Q. D. Wheeler (2004)}

All New World genera of Gymnetini have now been completely revised or reviewed by me since 1978 (see references), although two new genera are described herein. This taxonomic effort resulted in significant changes in the list of valid genera, species, and their synonyms since the catalogs of Schenkling (1921), Blackwelder (1944), and Krajčík (1998). While these catalogs may be useful for tracking the history of specific epithets, they are of little value to show the correct assignment of names, their synonyms, and their distributions since these are often incorrect.

A key is provided for the first time for the adults of all 27 genera of New World Gymnetini. The key is supplemented with a new checklist of all species names, their synonyms, and literature associated with each epithet that reflects the recent revisions or synopses. The key and checklist herein serve as a capstone summary of these revisions. An additional key is provided for 19 species in 10 genera of the known New World larval Gymnetini.

\section{Material and Methods}

The key characters and new generic and species descriptions were based on the following characteristics: length from apex of pronotum to apex of elytra (the head may or may not be deflexed and, if measured, could give a misleading length); width across humeri; color and markings; interocular width (number of transverse eye diameters across the frons); form and sculpturing of the head, pronotum, elytra, and pygidium; form of the protibial and mesometasternal processes; sculpturing and color of the abdominal sternites; and form of the male parameres. Punctures are considered simple unless otherwise noted. Minute punctures are generally not seen with $12.5 \mathrm{X}$ magnification but are easily seen with $50 \mathrm{X}$ magnification. Small punctures are easily seen with $12.5 \mathrm{X}$ magnification and can be seen with the naked eye. Large punctures are easily seen without the aid of instruments. Sparse punctures are characterized by numerous puncture diameters among them. Punctures moderate in density have 3-5 puncture diameters among them. Dense punctures have only $\leq 1-2$ puncture diameters among them. I use the phylogenetic species concept as outlined by Wheeler and Platnick (2000). This concept defines species as the smallest aggregation of (sexual) populations diagnosable by a unique combination of character states. 
Some morphological characters are illustrated to clarify specific statements in the identification key. The habitus images are meant to represent exemplars of each genus of New World Gymnetini since illustrating all species in the tribe is beyond the scope of this work.

The authors and dates following generic and species epithets in the checklist are considered as literature citations in this work and not simply taxonomic data as implied by the punctuation.

\section{Key to the Adults of the Genera of Gymnetini in the New World}

1. Basomedian lobe of pronotum covers less than half of scutellum (Fig. 17) ...

$1^{\prime}$ Basomedian lobe of pronotum strongly produced posteriorly, covering all but extreme tip of scutellum (Fig. 23)......5

2(1). Metafemur greatly enlarged in both sexes (Figs. 15, 17). Metatibial apex in male elongated into stout, acute spine and with 1 articulated spur (Fig. 16). Southern South America; 2 species

\section{Blaesia Burmeister (Fig. 17)}

2'. Metafemur not enlarged. Metatibial apex lacking elongated spine ......... 3

$3\left(2^{\prime}\right)$. Elytral surface strongly striate, rugopunctate, lacking cretaceous marks (Fig. 34). Northern Mexico; 2 species ....

Halffterinetis Morón and Nogueira (Fig. 34)

3'. Elytral surface not strongly striate, nearly smooth, with or without punctures, nearly always with cretaceous marks ................................ 4

$4\left(3^{\prime}\right)$. Length from apex of pronotum to apex of elytra $18 \mathrm{~mm}$ or longer. Elytra shiny black with transverse, bright cretaceous bands or spots at about middle (Fig. 27) or with small, cretaceous spot on lateral margin just behind middle. Mesometasternal process moderately long, extending past mesocoxae in lateral view. Southwestern USA to Guatemala; 6 species ..... Gymnetina Casey (Fig. 27)

4'. Length from apex of pronotum to apex of elytra less than $12.5 \mathrm{~mm}$. Elytra opaque dark reddish brown or piceous with numerous, transverse, dull cretaceous flecks. Mesometasternal process short, virtually obsolete, not extending past mesocoxae in lateral view. Northeastern and central Mexico; 1 species .... $5\left(1^{\prime}\right) . \quad$ Surface of head, pronotum, and elytra distinctly setose .....................6

5'. Dorsal surface not distinctly setose, head and anterior angles of pronotum occasionally with short setae ........ 7

6(5). Clypeal apex with marginal bead. Male protibia tridentate. Male abdominal sternites longitudinally sulcate at center (Fig. 40). Female tarsomeres slender. Southern Brazil, Bolivia; 2 species .... ... Hoplopygothrix Schürhoff (Fig. 41)

6'. Clypeal apex lacking marginal bead. Male protibia bidentate. Male abdominal sternites normal, planar, not longitudinally sulcate. Female tarsomeres short, compact (Fig. 50). Southern South America; 3 species

Neocorvicoana Ratcliffe and Micó (Fig. 51)

$7\left(5^{\prime}\right)$. Head with clypeal apex and/or frons with horn, keel, lobe, or prominence (Figs. 2, 18, 20) (only Allorrhina and Argyripa females lack armature) ................ 8

$7^{\prime}$. Head in both sexes lacking armature of any kind $\ldots \ldots \ldots \ldots \ldots \ldots \ldots \ldots \ldots \ldots \ldots \ldots \ldots$

8(7). Head and/or pronotum and elytra with scales or scale-like setae (Fig. 13). Mexico, Central America; 4 species ...

Balsameda Thomson (Fig. 14)

$8^{\prime}$. Dorsal surface lacking scales or scalelike setae ......................... 9

$9\left(8^{\prime}\right)$. Frons on each lateral margin above antennal insertion with short, pointed, anteriorly projecting horn, acute tooth, or laterally compressed ridge in at least males (Figs. 9, 18) ................. 10

$9^{\prime}$. Frons on each lateral margin lacking anteriorly projecting horn, acute tooth, or laterally compressed horn or ridge ........... 11

10(9). Frons, clypeus, and pygidium with long, dense, reddish brown setae (Fig. 18). Frons on lateral margin above antennal insertion with short, pointed, anteriorly projecting horn or acute tooth in both sexes (Fig. 18). Clypeal apex in both sexes with short horn. Length greater than $28 \mathrm{~mm}$. Panama, Costa Rica; 1 species ..... Chiriquibia Bates (Fig. 19)

10'. Frons, clypeus, and pygidium lacking long, dense setae. Male frons on lateral margin above antennal insertion with vertical, attenuate, laterally compressed horn or ridge (Fig. 9); clypeal apex lacking armature. Female lacking armature on frons or clypeus. Length less than $26 \mathrm{~mm}$. Central America, northern South America; 5 species .............. Argyripa Thomson (Fig. 10) 
11 $\left(9^{\prime}\right)$. Pronotum at center apex in males slightly produced, females with erect tubercle followed usually by shallow fovea. Cuba; 1 species ............... ..... Tiarocera Burmeister (Fig. 52)

11'. Pronotum at center apex in males not noticeably produced, females never with tubercle and fovea ............. 12

$12\left(11^{\prime}\right)$. Antennal scape as long as next 4 antennomeres combined (Fig. 35). Southern South America; 2 species

Heterocotinis Martínez (Fig. 36)

12'. Antennal scape short, less than length of next 4 antennomeres combined ........... 13

13(12'). Males with clypeal horn or protuberance and process on frons (Figs. 1-2); females lacking both of these (Fig. 3). Males with frontal process dorsoventrally flattened and free at its apex. South America; 9 species ................ Allorrhina Burmeister (Fig. 1)

13'. Both sexes with clypeal horn or protuberance and process on frons. Males with frontal process dorsoventrally flattened or not, apex free or fused to head (Fig. 20). USA south to Colombia and Venezuela; 27 species

Cotinis Burmeister (Fig. 21)

$14\left(7^{\prime}\right)$. Apex of clypeus emarginate or bilobed (Figs. 4, 23) ........................ 15

14'. Apex of clypeus truncate, broadly rounded, or produced medially ..................... 19

15(14). Mesometasternal process nearly flat, extending forwards in same plane as ventral axis of body, weakly or strongly produced (Fig. 6) ................... 16

15'. Mesometasternal process extending obliquely downwards from ventral axis of body (Fig. 22) or extending forwards and then recurving upwards apically (Fig. 24) ... .. 17

16(15). Antennal club subequal in length to entire stem (Fig. 43). Lateral margin of elytra completely, broadly chalky white. Ecuador, possibly French Guiana; 1 species ...

Jansonia Schürhoff (Fig. 43)

16'. Antennal club shorter than entire stem but longer than antennomeres 2-7. Elytra lacking broad, chalky white band on lateral margin, instead lacking any contrasting coloration (Fig. 5) or with white spots or small, transverse bands (Fig. 8). Central Mexico to northwestern South America, West Indies; 14 species ..................... Amithao Thomson (Figs. 5-8)

17(15'). Mesometasternal process extending obliquely downwards from ventral axis of body (Fig. 22). Panama to Argentina; 3 species

Desicasta Thomson (Fig. 23)

17'. Mesometasternal process extending forwards and then recurving upwards apically (Fig. 24) ................... 18

$18\left(17^{\prime}\right)$. Dorsal color bright green with numerous small, black spots. Panama, Costa Rica; 1 species

Hadrosticta Kraatz (Fig. 33)

18'. Dorsal color black or dark reddish brown with pale yellow or ochre markings on lateral margins of elytra. Mexico to northwestern South America; 2 species ....

Guatemalica Neervoort

van de Poll (Figs. 24-25)

$19\left(14^{\prime}\right)$. Sutural apices of elytra usually prolonged into spines (Fig. 39). Clypeal apex narrowly reflexed. Each elytron usually with complete, mediodiscal costa and a laterodiscal costa that is depressed on mediodiscal area; occasionally with indistinct elytral costae or 2 weakly raised, complete costae. Surface with large, n-shaped punctures arranged longitudinally in striae in depressions between costae (Fig. 39); occasionally n-shaped punctures not in rows but enclosed in a reddish brown to black spot, giving elytra a spotted appearance. Mexico to Argentina, West Indies; 21 species

Hoplopyga Thomson (Fig. 39)

19'. Sutural apices of elytra usually not prolonged into spines. Clypeal apex not noticeably reflexed. Each elytron usually with indistinct elytral costae or 2 nearly obsolete costae. Surface usually lacking large, n-shaped punctures arranged longitudinally in striae (some Gymnetis species with these punctures) ........................ 20

20(19'). Mesometasternal process usually large, extending moderately to strongly obliquely downwards from ventral axis of body, apex narrowly or broadly subquadrate or bluntly rounded (Fig. 28). Southern USA to Argentina; 56 species ................. Gymnetis

MacLeay (Figs. 28-31)

20'. Mesometasternal process small, nearly flat, extending forwards in same plane or nearly so as ventral axis of body, apex slightly recurved or not ............. 21

21(20'). Dorsal surface bright metallic green with large, black vittae. Colombia; 1 species .......................... ...... Howdenypa Arnaud (Fig. 42) 
21'. Dorsal surface velutinous or opaque, not bright green ..................... 22

22(21'). Mesometasternal process with long, recumbent, yellow setae on metasternal part (Fig. 44). Southern Brazil, Paraguay; 1 species

Macrocranius Schürhoff (Fig. 45) Mesometasternal process glabrous or with only short, sparse setae ....... 23

$23\left(22^{\prime}\right)$. Dorsal surface completely black or reddish brown with (Fig. 12) or without small, sparse, black speckles ........ 24

23'. Dorsal surface with contrasting pattern of cretaceous, ochre, orange, or yellow bands on black ground color or dark "cloudings" on brown, piceous, grey, ochre, or yellowish green ground color, usually not with black speckles. If with black speckles (2 species), then speckles dense (Fig. 48), size smaller, length less than $21 \mathrm{~mm}$............25

24(23). Dorsal surface velutinous black or reddish brown. Size large, length 22-29 mm. Brazil, Paraguay; 2 species

Badelina Thomson (Fig. 12)

24'. Dorsal surface shiny black. Size small, length 16-17 mm. Martinique; 1 species

Madiana Ratcliffe and Romé, new genus (Fig. 46)

$25\left(23^{\prime}\right)$. Elytra with contrasting pattern of slender, transverse, ochre bands radiating from midline on black ground color (Fig. 11). Entire dorsal surface usually densely, coarsely punctate. Southern Brazil; 1 species

Astroscara Schürhoff (Fig. 11)

25'. Elytra with or without contrasting pattern of transverse bands; if with contrasting bands, then bands broad (Figs. 47,49 ) and entire dorsal surface not densely, coarsely punctate .......... 26

$26\left(25^{\prime}\right)$. Prosternum with distinct "throat spur" (as in Fig. 32). Elytra with transverse, black bands or vittae on ochre, yellow, or orange ground color (Figs. 47, 49) or dense, black speckles on ochre ground color (Fig. 48). Southern Mexico to Argentina; 5 species Prosternum lacking distinct "throat spur" (Fig. 37). Elytra with dark "cloudings" on brown, piceous, grey, ochre, or yellowish green ground color or, if with transverse bands (1 species), then cretaceous bands on black ground color. Southwestern USA to Guatemala and southern South America; 8 species

.... Hologymnetis Martínez (Fig. 38)

\section{Key to the Known Third Instars of New World GyMnetini}

(Modified from Micó et al. 2001, Morón and Arce 2002, and Ibarra-Polesel et al. 2017)

1. Palidia present ............................ 2

1'. Palidia absent. Southwestern USA to northwestern Mexico

Gymnetina cretacea (LeConte)

2. Raster with each palidium consisting of 2 or more irregular rows of pali. Terminal antennomere with 3-7 dorsal sensory spots. Haptomeral process absent ................ 3

$2^{\prime}$. Raster with palidia monostichous. Other characters not as above .................... 5

3. Tarsungulus with 7 setae. Maxillary stridulatory area with 5 teeth. Terminal antennomere with 3 ventral sensory spots. Southwestern USA to Honduras ....... Hologymnetis cinerea (Gory and Percheron)

3'. Tarsungulus with 10-12 setae. Maxillary stridulatory area with 7-9 teeth. Terminal antennomere with 5-13 ventral sensory spots (Cotinis species)

4. Raster with inner row of each palidium having 9-10 pali slightly larger than those in outer row. Southeastern USA

Cotinis nitida (Linnaeus)

4'. Raster with inner row of each palidium having 7-10 pali much stouter and larger than those in outer row. Southwestern USA to northern South America

.. Cotinis mutabilis (Gory and Percheron)

5. Dorsum of abdominal segment VII with 3 annulets

5'. Dorsum of abdominal segment VII with 2 annulets ................................. 10

6. Terminal antennomere with 10-20 sensory spots .................................. 7

6'. Terminal antennomere with 5-8 sensory spots

7. Stemmata present, well-defined. Haptomeral region with 14-16 heli in a transverse row. Each palidium consisting of a row of 17-20 pali. Mexico to Panama

Amithao haematopus (Schaum)

7'. Stemmata absent. Haptomeral region with 10-15 heli in a transverse row. Each palidium consisting of a row of 23-26 pali. Southern Mexico to Ecuador

Argyripa lansbergei (Sallé)

8. Terminal antennomere with 8 sensory spots. Maxillary stridulatory area with 7 teeth. 
Septula very narrow, elongate, length 9 times width. Argentina, Brazil, Paraguay, and Uruguay .... Blaesia atra Burmeister

$8^{\prime}$. Terminal antennomere with 5-6 sensory spots. Maxillary stridulatory area with 5 teeth. Septula oval or elongate, length 2.5-3.5 times width (Gymnetis species, in part) 9

9. Terminal antennomere with 6 sensory spots. Haptomeral region with a transverse row of 19-20 heli. Septula oval, length 2.5 times width. Argentina, Brazil, Peru, Paraguay and Uruguay .....

Gymnetis chalcipes

(Gory and Percheron)

$9^{\prime}$. Terminal antennomere with 5 sensory spots. Haptomeral region with a transverse row of 14 heli. Septula elongated, length 3.5 times its width. Peru and Brazil

Gymnetis rufilatris (Illiger)

10. Tarsungulus with 5-7 setae ... 11

$10^{\prime}$. Tarsungulus with $8-15$ setae ............ 13

11. Distance between 2 lobes of respiratory plate of spiracles slightly less than dorsoventral diameter of bulla, or as long as such diameter. Right mandible with 2 scissorial teeth. Terminal antennomere with 5 sensory spots. Argentina, Brazil, Paraguay, Peru, and Uruguay

Neocorvicoana reticulata (Kirby)

11'. Distance between 2 lobes of respiratory plate of spiracles much less than dorsoventral diameter of bulla, or almost surrounding it. Right mandible with 3 scissorial teeth. Terminal antennomere with 5-10 sensory spots (Marmarina species) .. 12

12. Terminal antennomere with 10 sensory spots. Maxillary stridulatory area with row of 9 acute teeth. Each palidium consisting of an irregular row of 12-13 pali. Argentina, Brazil, Paraguay, and Uruguay .............. ... Marmarina tigrina (Gory and Percheron)

$12^{\prime}$. Terminal antennomere with 5-7 sensory spots. Maxillary stridulatory area with row of 6 acute teeth. Each palidium consisting of an irregular row of 19-20 pali. Southern Mexico to the Amazon regions of Brazil, Colombia, Peru, and Bolivia

Marmarina maculosa (Olivier)

13. Distance between 2 lobes of respiratory plate of spiracles subequal to dorsoventral diameter of bulla (Hoplopgyga species) ....

14

13'. Distance between 2 lobes of respiratory plate of spiracles much less than dorsoventral diameter of bulla, or almost surrounding it (Gymnetis species, in part) .............. 16

14. Right mandible with 3 scissorial teeth. Haptomeral region with a transverse row of 12-19 heli. Each palidium consisting of an irregular row of 14-18 pali .
14'. Right mandible with 2 scissorial teeth. Haptomeral region with a transverse row of 8-11 heli. Each palidium consisting of an irregular row of $18-25$ pali. Argentina, Brazil, Paraguay, and Colombia

Hoplopyga singularis

(Gory and Percheron)

15. Tarsungulus with 9-10 setae. Haptomeral region with a transverse row of 12 heli. Terminal antennomere with 4 dorsal sensory spots. Mexico to northern Argentina

Hoplopyga liturata (Olivier)

15'. Tarsungulus with 11-12 setae. Haptomeral region with a transverse row of 17-19 heli. Terminal antennomere with 3 dorsal sensory spots. South America

Hoplopyga brasiliensis

(Gory and Percheron)

16. Each palidium consisting of an irregular row of $18-23$ pali ............................ 17

$16^{\prime}$. Each palidium consisting of an irregular row of $10-16$ pali ........................... 18

17. Anterior frontal setae absent. Tarsungulus with 9-13 setae. Spiracles of abdominal segments I-VIII similar in size. Panama to northern Argentina.

Gymnetis pantherina (Blanchard)

17'. Anterior frontal setae present. Tarsungulus with 8 setae. Spiracles of abdominal segments I-VIII increasing in size towards posterior segments. Mexico and Guatemala

Gymnetis difficilis Burmeister

18. Stemmata absent. Anterior frontal setigerous punctures absent. Haptomeral region with a transverse row of 12-14 heli. Septula narrow, elongated, length 5 times width. Brazil, Bolivia, Ecuador, Colombia, French Guiana, and Peru .......... Gymnetis holosericea (Olivier)

$18^{\prime}$. Stemmata present. Anterior frontal setigerous punctures present. Haptomeral region with a transverse row of 10-12 heli. Septula oval, length 2.5 times width. Mexico to Panama...

Gymnetis sallei Schaum

Gymnephoria Ratcliffe, new genus

Zoobank.org/urn:lsid:zoobank.org:act: 0907BFA3-8AB3-42BA-9171-0A6E663AAFEE

Type Species. Gymnephoria spilota Ratcliffe, new species, here designated.

Description. Form: Body form elongate, subrectangular, dorsal surface flattened. Length 11.5-12.5 mm. Ground color dull black or dark reddish brown with chalky white vittae, flecks, and spots variably present on head, pronotum, elytra, mesepimeron, pygidium, metathorax, procoxae, meso- and metafemora, metasternum, and sternites 

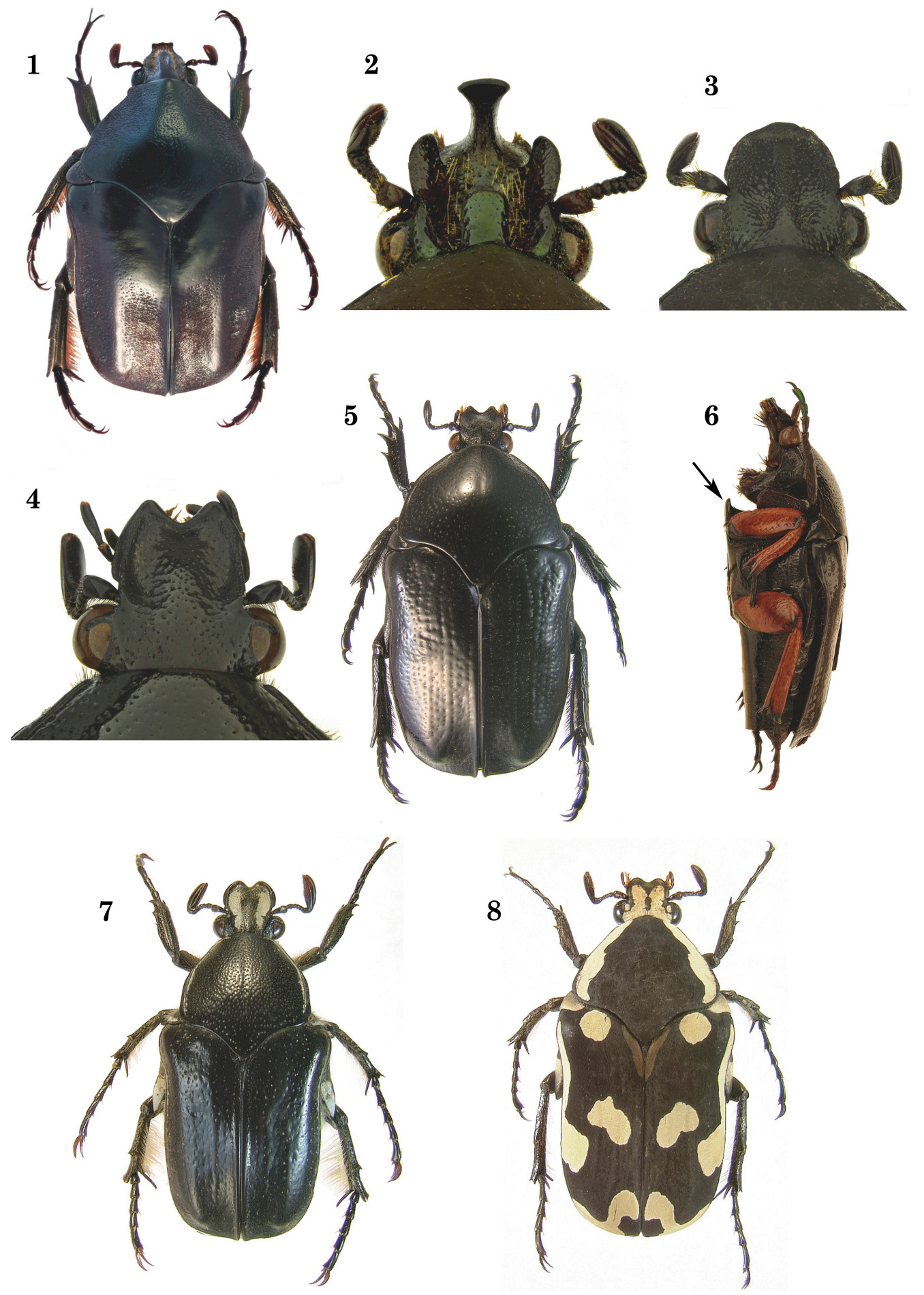

Figs. 1-8. New World Gymnetini. 1) Allorrhina scabriuscula; 2) Allorrhina menetriesii, male head; 3) $A$. menetriesii, female head; 4) Amithao anthracinus, male head; 5) A. anthracinus; 6) Amithao haematopus, mesometasternal process (arrow); 7) Amithao tristis; 8) Amithao marginicollis. 

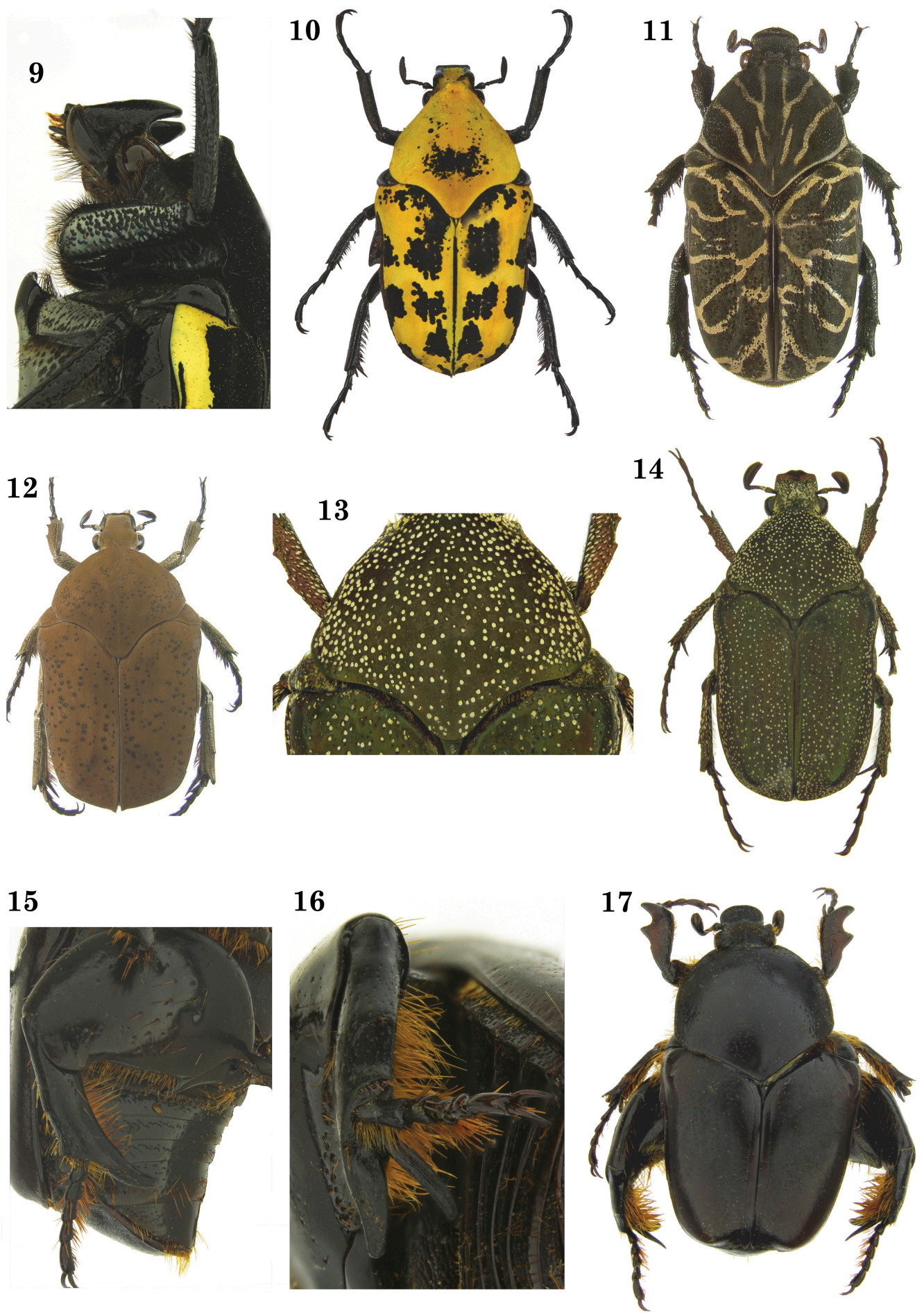

Figs. 9-17. New World Gymnetini. 9) Argyripa anomala, male head; 10) Argyripa subfasciata; 11) Astroscara flavoradiata; 12) Badelina pygidialis; 13) Balsameda pulverulenta, pronotum; 14) B. pulverulenta; 15) Blaesia atra, male hind leg; 16) B. atra, metatibia; 17) B. atra. 

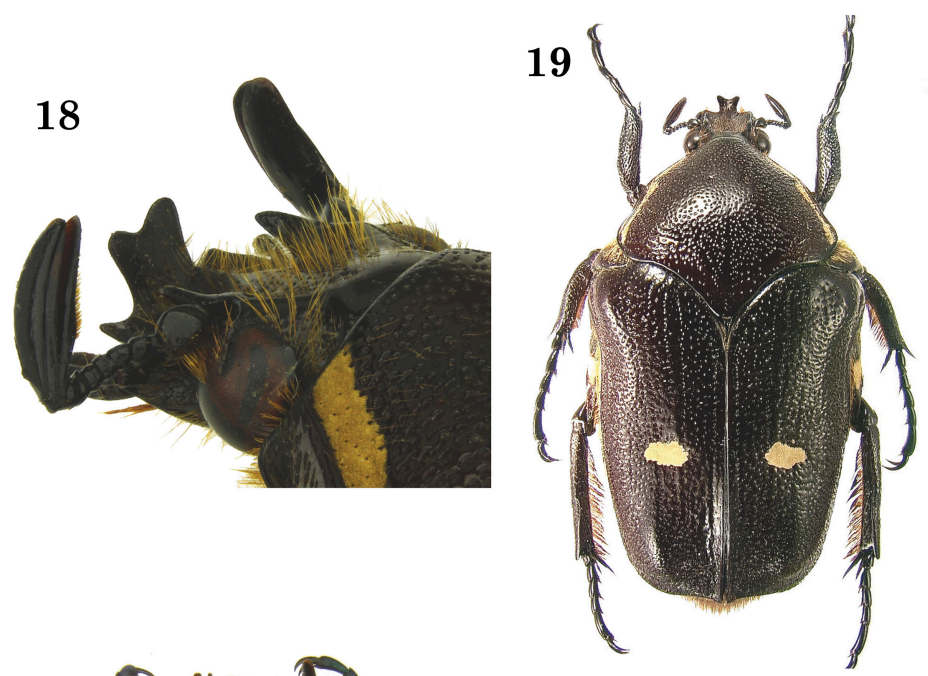

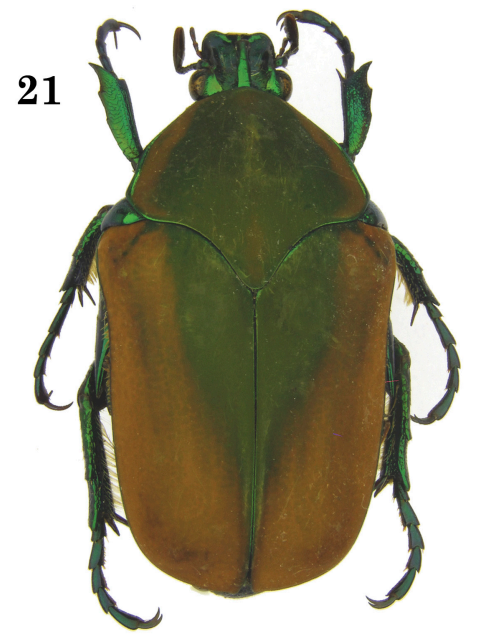

22
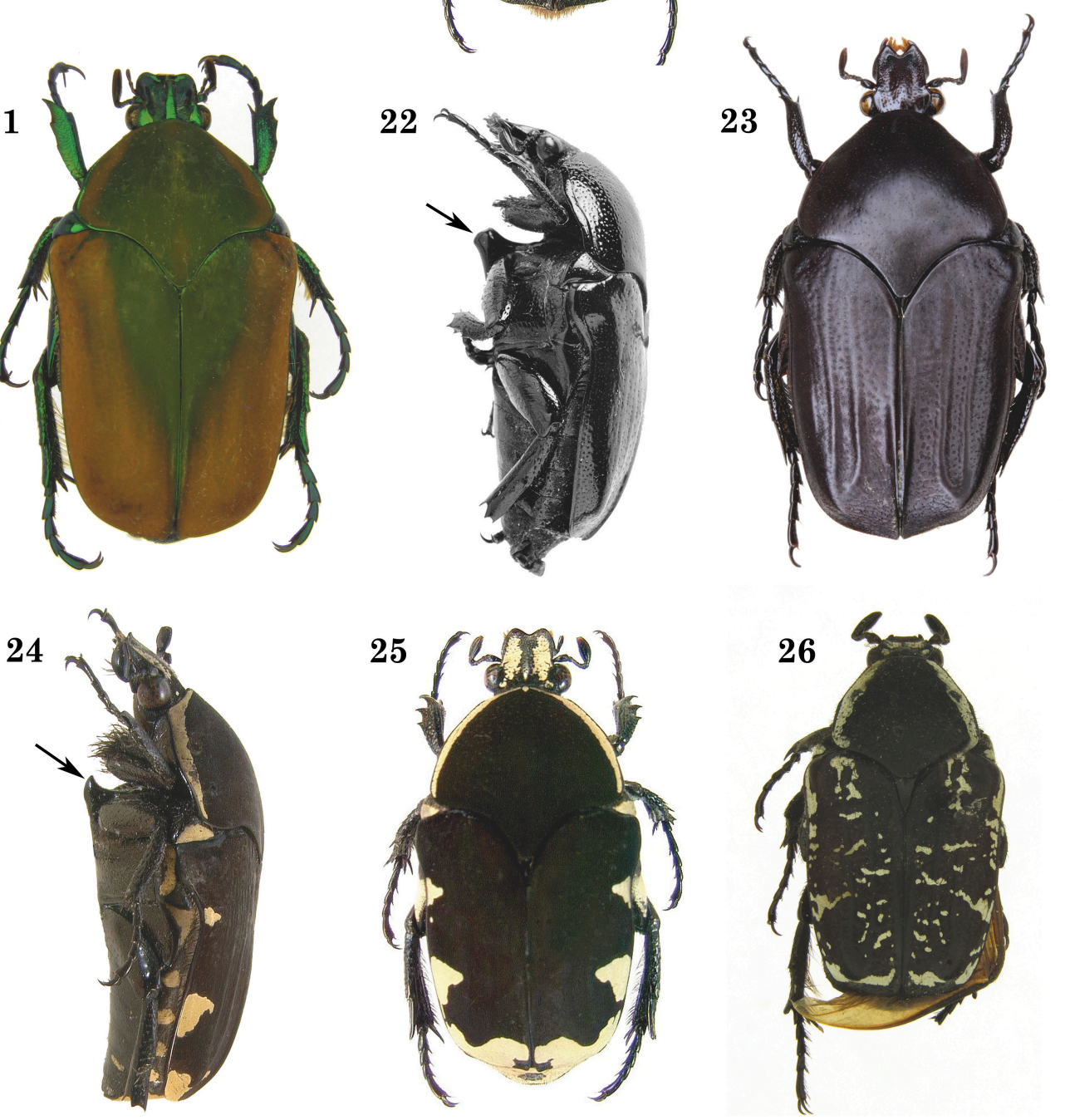

Figs. 18-26. New World Gymnetini. 18) Chiriquibia insignis, male head; 19) C. insignis; 20) Cotinis mutabilis, male head, clypeal and frontal horns (arrows); 21) C. mutabilis; 22) Desicasta reichei, mesometasternal process (arrow); 23) Desicasta lobata; 24) Guatemalica hueti, mesometasternal process (arrow); 25) G. hueti; 26) Gymnephoria spilota, holotype. 

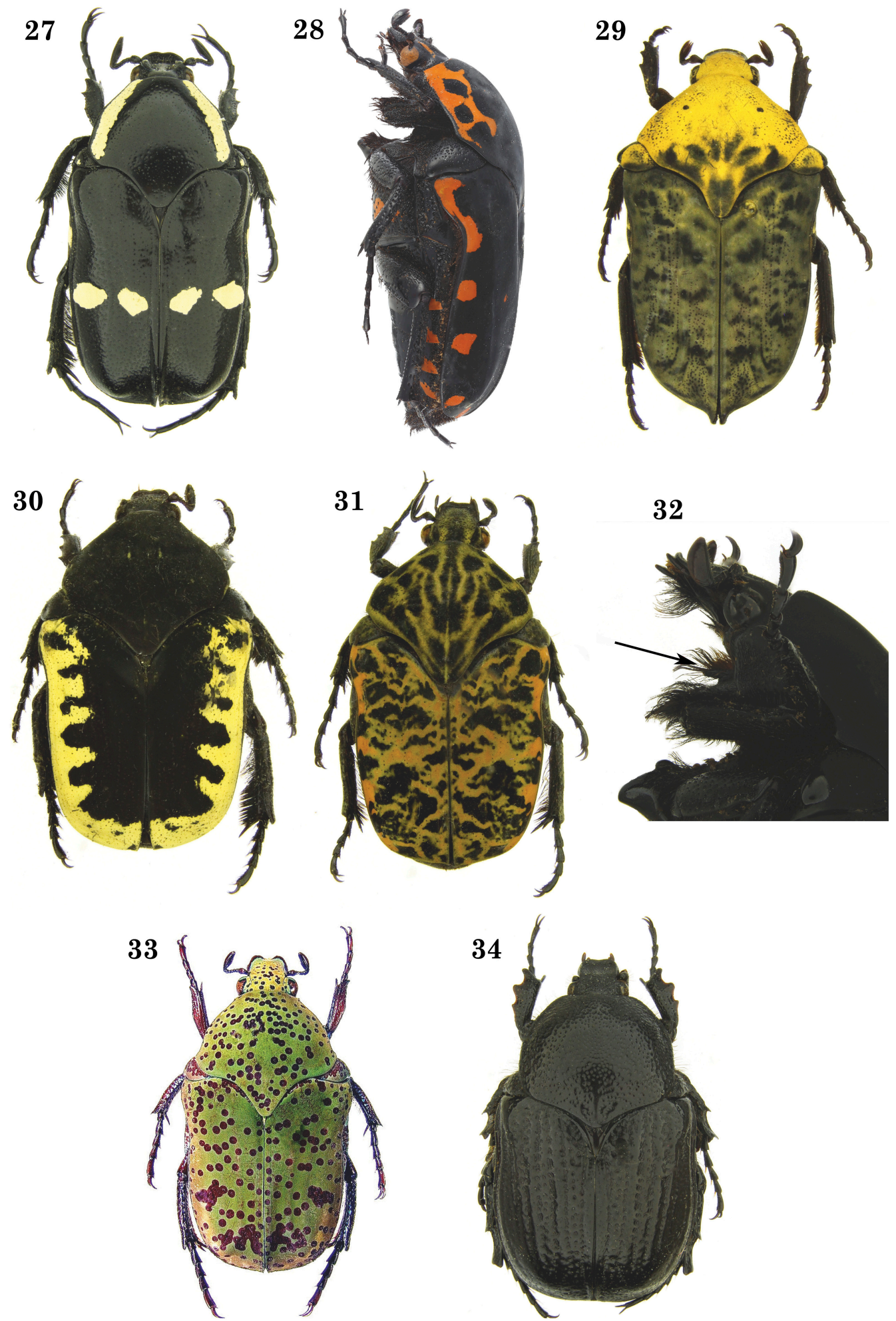

Figs. 27-34. New World Gymnetini. 27) Gymnetina cretacea cretacea; 28) Gymnetis buckleyi; 29) Gymnetis flaveola; 30) Gymnetis flavomarginata; 31) Gymnetis goryi; 32) Gymnetis holosericea, throat spur (arrow); 33) Hadrosticta viridiflua; 34) Halffterinetis gonzaloi. 

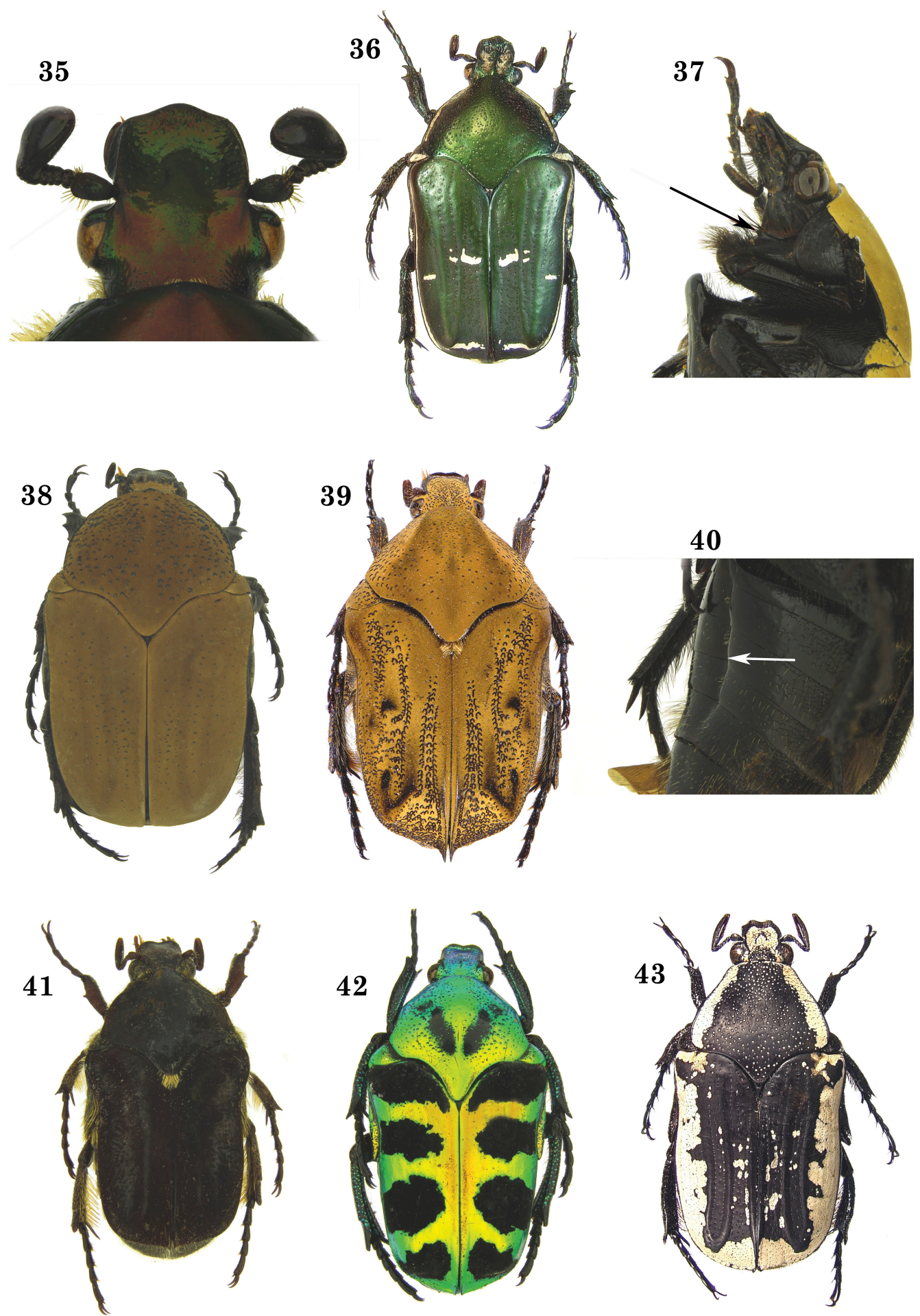

Figs. 35-43. New World Gymnetini. 35) Heterocotinis semiopaca, head; 36) Heterocotinis terminata; 37) Hologymnetis cinerea, throat spur absent (arrow); 38) H. cinerea; 39) Hoplopyga liturata; 40) Hoplopygothrix atropurpurea, abdominal sulcus (arrow); 41) H. atropurpurea; 42) Howdenypa gloriosa; 43) Jansonia anceps. 


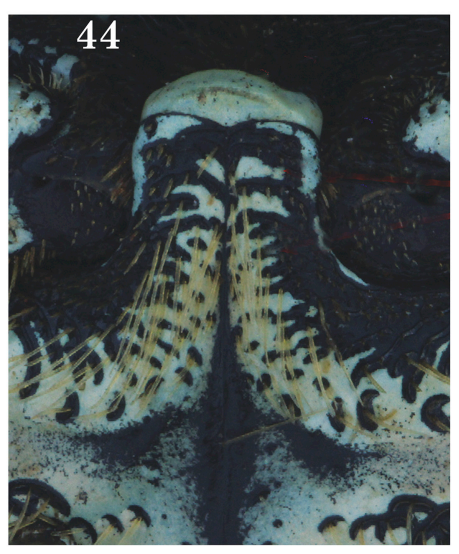

45
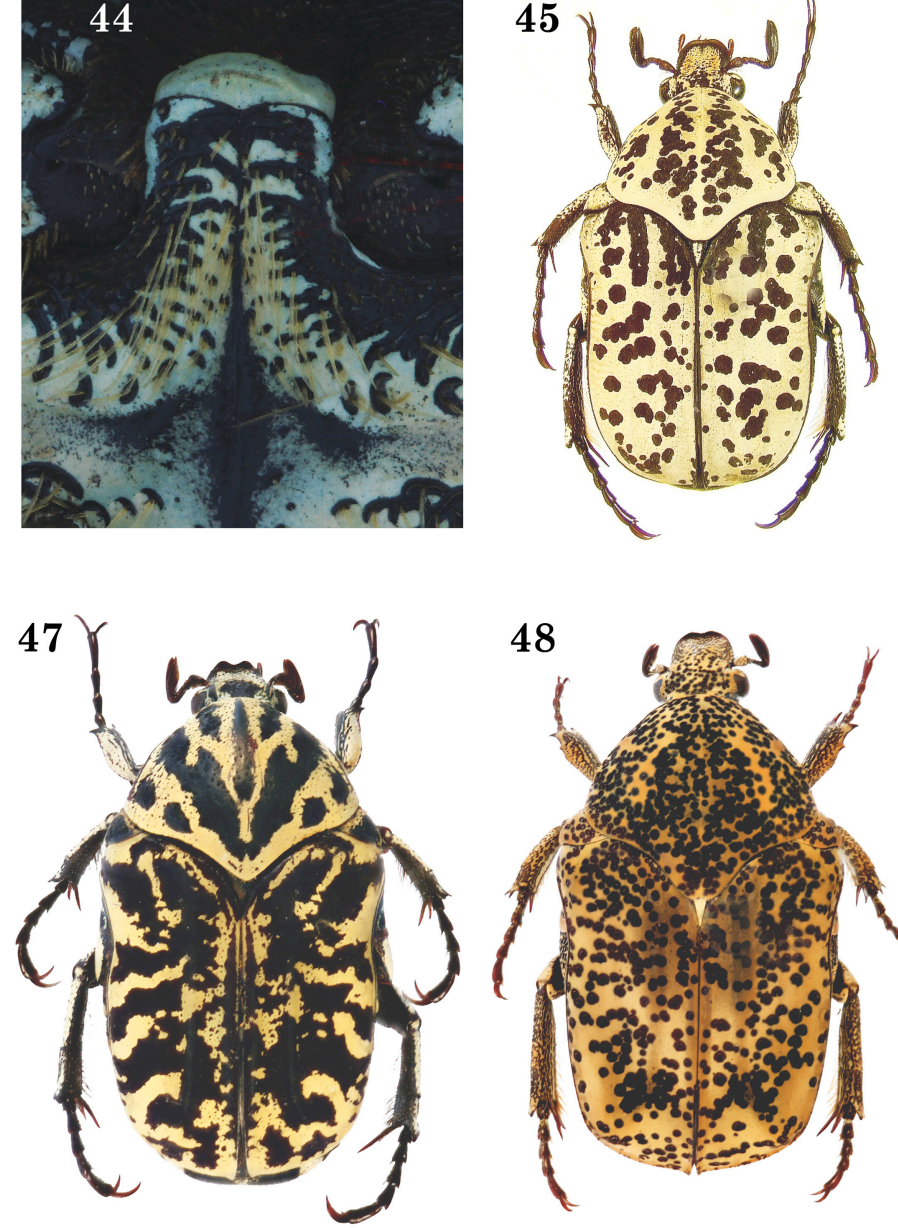

48
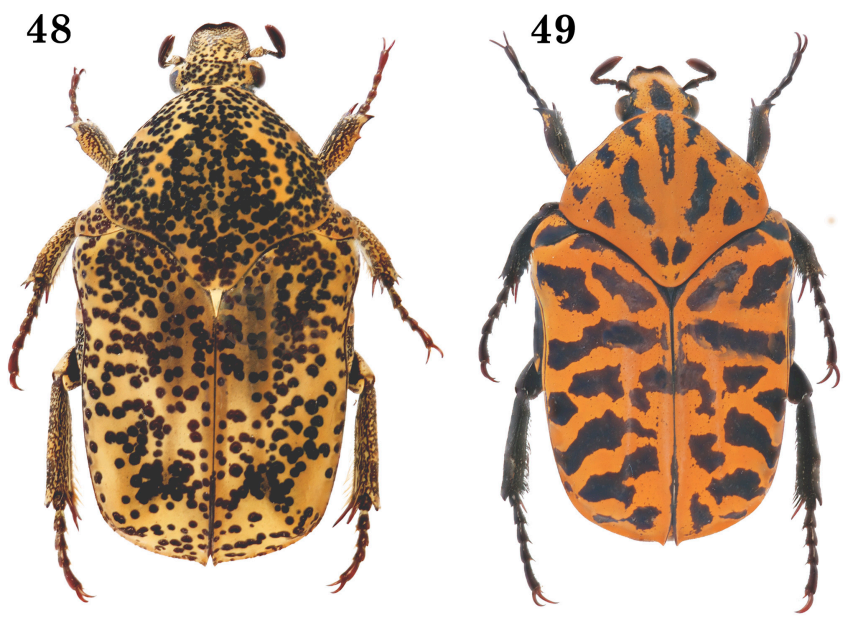

52

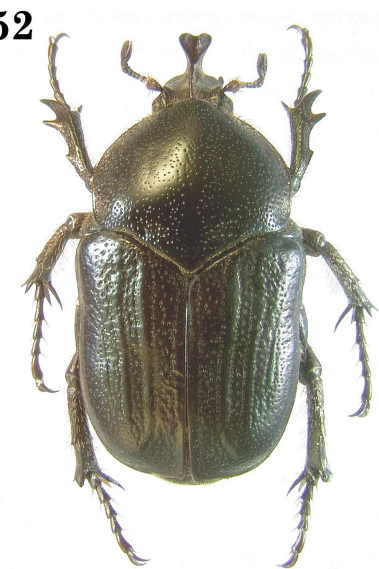

Figs. 44-52. New World Gymnetini. 44) Macrocranius similis, mesometasternal process; 45) M. similis; 46) Madiana brigitteae, holotype; 47) Marmarina argentina; 48) Marmarina insculpta; 49) Marmarina tigrina; 50) Neocorvicoana reticulata, female metatarsus; 51) $N$. reticulata, dorsal and ventral views; 52) Tiarocera cornuta. 
1-5. Head: Lacking armature. Clypeus subquadrate, apex truncate. Antenna with 10 antennomeres, club long, distinctly longer than antennomeres 2-7. Pronotum: Basomedian lobe projecting posteriorly, covering about half of scutellum. Elytra: Sutural and 2 discal costae elevated, moderately large, shallow punctures between costae. Pygidium: Surface weakly convex. Venter: Prosternal process minute, virtually obsolete. Mesometasternal process short, nearly obsolete, not extending past mesocoxae, apex rounded. Legs: Protibia weakly tridentate. Parameres: Form simple, subrectangular in caudal view with bluntly rounded apex.

Distribution. Northeastern and central Mexico.

Diagnosis. In gestalt, Gymnephoria resembles some specimens of Euphoria Burmeister (Cetoniini) because of size, color, and markings, especially E. lurida (Fabricius) or E. sepulcralis (Fabricius). Gymnephoria is distinguished from other Gymnetini that occur sympatrically, namely species of Balsameda, Cotinis, Guatemalica, Gymnetina, Gymnetis, Halffterinetis, Hologymnetis, and Hoplopyga, by its small size (less than $12.5 \mathrm{~mm}$ ), opaque, dark reddish brown or black elytra with dull, cretaceous flecks, scutellum partly exposed, and nearly obsolete mesometasternal process. Its size is similar to that of the smallest species of Hoplopyga, Hoplopygothrix, and Neocorvicoana.

Etymology. The epithet Gymnephoria is a combination of the Greek combining forms gymnos, meaning "bare or naked" in reference to the glabrous dorsal surface, and phero, meaning "to bear" in reference to bearing a glabrous dorsum. It is also a play on the names Gymnetis and Euphoria since Gymnephoria is clearly a member of the Gymnetini (produced pronotal basal lobe) but appears similar to some species of Euphoria in the Cetoniini by virtue of size, color, and cretaceous markings. The gender is feminine. It has nothing to do with, and is spelled differently than, the psychological term gymnophoria, meaning to be mentally undressed.

\section{Gymnephoria spilota Ratcliffe, new species Zoobank.org/urn:lsid:zoobank.org:act: 70C1EBCB-DC27-48F3-A352-816036582DE5}

(Figs. 53-55)

Type Material. Holotype male, labeled "Mexico Monterrey / Siesta Trailer Park / 10-VII-69 // Coll: Ward, / Tenorio and / Bennett" and with my red holotype label. Paratype male labeled: "Mexico Km 1226 / Hwy 45, S. of / La Rosalana / 16-VII-69 // Coll: Ward, / Tenorio and / Bennett" and with my yellow paratype label. Holotype deposited at UNSM, paratype in BCRC.

Description. Holotype Male. Length $11.5 \mathrm{~mm}$; width across humeri $6.3 \mathrm{~mm}$. Ground color black, weakly shiny, and with chalky white vittae, flecks, or spots as follows: Head with 2 broad, longitudinal, parallel vittae extending from mesad of each eye to middle of clypeus. Pronotum with broad vitta along each lateral margin. Elytra with flecks, spots, and broken bands (Fig. 53). Mesepimeron chalky white on posterior half. Pygidium with suboval vitta on each side. Procoxa with small spot on side. Mesoand metafemora each with small spot on posterior margin on venter near apex. Metasternum with small spot on posterolateral corner. Sternites 1 (left side only) to 3 each with small spot on posterolateral corner; slightly larger spot on anterior margin of sternites 3-5 either side of middle. Head: Entire surface with moderately large, dense punctures, those on frons with moderately long, black setae. Clypeus subquadrate, apex truncate and distinctly reflexed. Interocular width equals about 6.0 transverse eye diameters. Antenna with 10 antennomeres, club distinctly longer than antennomeres 2-7. Pronotum: Surface with punctures moderate in size and density. Basomedian lobe distinct but covering less than half of scutellum. Elytra: Sutural and 2 discal costae each strongly elevated, apices of discal costae merging just before apical umbone. Surface between costae and on sides with punctures moderate in size and density. Apices at suture subquadrate. Pygidium: Surface with punctures moderate in size and density, some setigerous; seta minute, black; lateral angles and apex rugulose. Surface weakly convex in lateral view. Venter: Metasternum with large, dense, round, setigerous punctures; setae long, dark brown. Mesometasternal process short, not extending past mesocoxae, apex rounded. Abdominal sternites 1-6 each with moderately large, dense, setigerous punctures on lateral fifths; setae short, dense, dark brown. Legs: Protibia weakly tridentate, basal tooth nearly obsolete. Parameres: Form elongate in caudal view, subrectangular, lateral margins constricted at middle, apices bluntly rounded (Figs. 54-55).

Variation. Male (1 paratype). Length $12.2 \mathrm{~mm}$; width across humeri $6.7 \mathrm{~mm}$. As holotype except in the following respects: Dorsal surface with dark reddish brown ground color. Elytra: Apices each weakly produced into small, acute angle. Pygidium: Setae short, not minute. Venter: Metasternum on posterolateral corner with large, chalky white spot. Sternites $2-5$ on lateral thirds each with large, transverse, chalky white vitta. Female remains unknown.

Etymology. The epithet is adjectival and derived from the Greek spilotos, meaning "flecked or spotted" in reference to the numerous, small, cretaceous flecks on the elytra. It is feminine to agree with the gender of the genus.

Distribution. Gymnephoria spilota is known only from Monterrey in northeastern Mexico and 


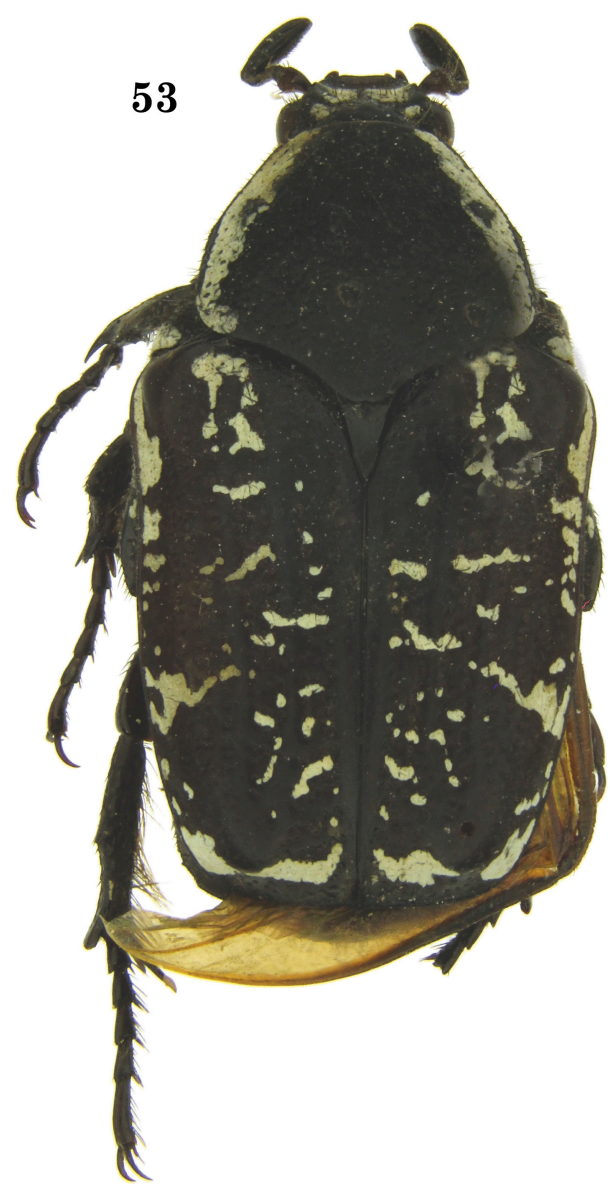

\section{4}
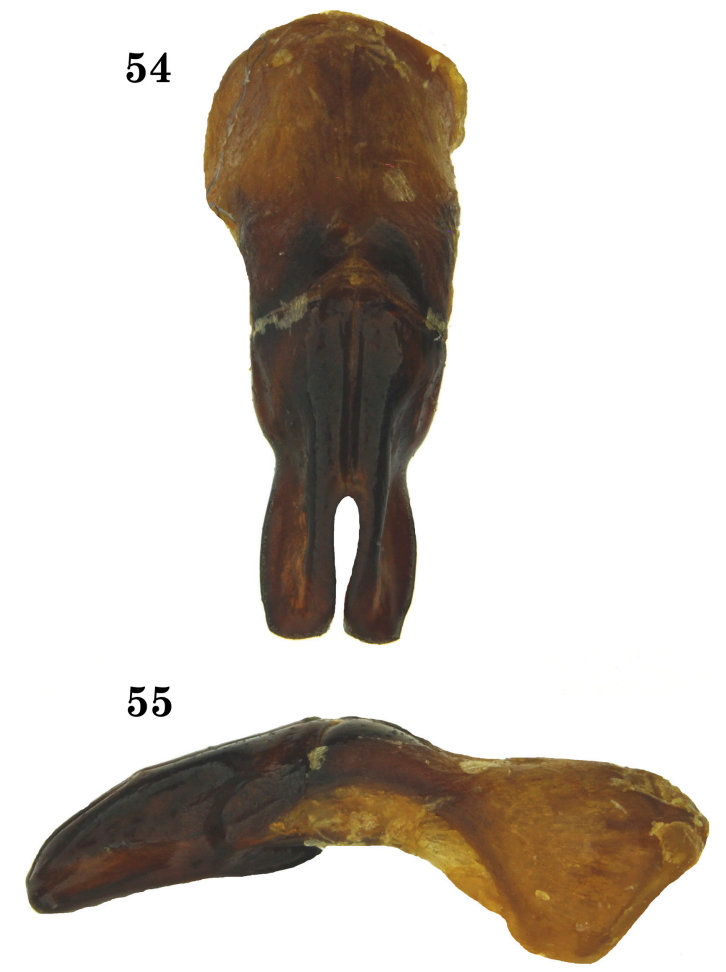

Figs. 53-55. Gymnephoria spilota. 53) Holotype, dorsal habitus; 54-55) Parameres, caudal and lateral views, respectively.

Aguascalientes in central Mexico. I am unable to find a "La Rosalana" near km 1226 just south of Aguascalientes, although there is a short street named "Resolana" and a Pemex gas station at km 1226. I was unable to locate any of the collectors from 50 years ago to seek additional data.

Locality Records. MEXICO (2): AGUASCALIENTES (1): Hwy 45 S. of La Rosalana [sic] (km 1226). NUEVO LEÓN (1): Monterrey.

Temporal Distribution. July (2).

Diagnosis. In gestalt, G. spilota resembles some specimens of E. lurida or E. sepulcralis (both Cetoniini) because of size, color, and markings. Gymnephoria spilota is the only known species in its genus, and the generic characters will distinguish it from other Gymnetini that occur sympatrically, namely species of Balsameda, Cotinis, Guatemalica, Gymnetina, Gymnetis, Halffterinetis, Hologymnetis, and Hoplopyga (see key to genera). Its small size (less than $12.5 \mathrm{~mm}$ ), opaque, dark reddish brown or black elytra with dull, cretaceous flecks, partly exposed scutellum, and nearly obsolete mesometasternal process will distinguish it from other New World Gymnetini.

Natural History. There are no data associated with the specimens to indicate how they were collected or possibly on what, if any, flowers.

\section{Madiana Ratcliffe and Romé, new genus} Zoobank.org/urn:lsid:zoobank.org:act: 0BCA66BA-B066-487C-93DC-DF9534F19CB6

Type Species. Madiana brigitteae Ratcliffe and Romé, new species, here designated.

Description. Form: Rhomboidal, sides slightly tapering from humeri towards apex of elytra, dorsum nearly flat. Color black, partially shiny, partially opaque. Length 16-17 mm. Head: Clypeal apex truncate and narrowly reflexed. Antenna with 10 antennomeres. Pronotum: Basomedian lobe strongly produced, lobe covering all but tip of 
scutellum. Sides with broad marginal bead, anterior and basal margins lacking bead. Elytra: Widest at base, posthumeral emargination distinct. Bead present on lateral margins. Surface with rows of moderately large punctures and raised, parallel costae at suture and 2 on disc. Pygidium: Surface transversely strigose in males, concentrically rugose in females, weakly convex in both sexes. Venter: Mesometasternal process (lateral view) short, bluntly rounded and bulbous, projecting only slightly obliquely from ventral axis of body. Legs: Protibia tridentate in both sexes. Metatibia at apex subtruncate and with 2 long, slender spurs. Parameres: Form subrectangular in caudal view, flared on lateral edge at mid-shaft, with small angle or tooth apicolaterally, apices rounded.

Diagnosis. When Daniel Romé and his wife, Brigitte, first collected what is now the allotype of this species, they could not readily place it to a genus of cetoniines. When I received the specimen for examination in March 2018, I could not place it to a known genus due, in part, because Daniel fell on the parcel on the way to the post office, and so the specimen was flattened and disarticulated. The discovery of a second specimen (the male holotype) led to further research to determine the identity of these specimens, including the possibility that they might have originally been from Africa or Asia and accidentally introduced into Martinique. My examination revealed a unique combination of character states for New World Gymnetini that were indicative of a new, undescribed genus and species that Romé and I describe here.

The only known species of Madiana is distinguished from species in other genera of New World Gymnetini by the following combination of characters: prominent basomedian pronotal lobe present (lobe covering less than half of scutellum in Blaesia, Halffterinetis, and Gymnetina; surface of head glabrous (setose in Hoplopygothrix and Neocorvicoana); head unarmed (head with horns, keel or lobes in Balsameda, Chiriquibia Bates, Argyripa, Tiarocera, Heterocotinis, Allorrhina, and Cotinis); clypeal apex truncate (emarginate or bilobed in Jansonia, Amithao, Desicasta, Hadrosticta, and Guatemalica); sutural apices of elytra quadrate (apices spinose in Hoplopyga); mesometasternal process short, bulbous, projecting only slightly from ventral axis of body (mesometasternal process usually large, extending moderately to strongly obliquely downwards from ventral axis of body in Gymnetis or process small, nearly flat and extending forwards in same plane or nearly so as ventral axis of body in Howdenypa); mesometasternal process with sparse setae (mesometasternal process with long, recumbent, yellow setae on metasternal part in Macrocranius); prosternum with distinct "throat spur" (lacking "throat spur" in Hologymnetis); dorsal surface completely black (dorsal surface with contrasting pattern of cretaceous, ochre, orange, or yellow bands or dark "cloudings" on brown, piceous, grey, ochre, or yellowish green ground color in Astroscara and Marmarina); size small, length less than $20 \mathrm{~mm}$ (size large, greater than $22 \mathrm{~mm}$ in Badelina).

Only a few New World Gymnetini occur in the West Indies: Hoplopyga antilliana Ratcliffe (Grenada), Gymnetis guadalupiensis Gory and Percheron (Guadeloupe), Gymnetis lanius (Linnaeus) (Jamaica, Cayman Islands), Gymnetis marmorea (Olivier) (possibly Dominica), Gymnetis puertoricensis Ratcliffe (Puerto Rico), Gymnetis rudolphi (Frölich) (St. Lucia, the Grenadines, Dominica), Gymnetis stellata (Latreille) (República Dominicana), Gymnetis sternalis Chevrolat (Cuba), and Gymnetis undata (Olivier) (Hispaniola), but no gymnetine has ever been found in Martinique.

Etymology. Martinique may be a corruption of the Carib Indian name Madiana or Madinina, meaning "the Island of Flowers" (Cornevin 2018). The new generic name, Madiana, reflects this heritage and is feminine in gender.

\section{Madiana brigitteae Ratcliffe and Romé, new species}

Zoobank.org/urn:lsid:zoobank.org:act: 96702B33-BBB3-4F0A-A7C3-D3A11B4299CA (Figs. 56-59)

Type Material. Holotype male labeled "MARTINIQUE / Montagne du Vauclin / 6052'49.05W, 14³3'27.98N / III-15-2018 / D. \& B. Romé" and with our red holotype label. Allotype female with same data but III-1-2018 and with our red allotype label. Holotype and allotype deposited at the $\mathrm{Mu}-$ seum National d'Histoire Naturelle, Paris, France.

Description. Holotype Male. Length $16.6 \mathrm{~mm}$; width across humeri $9.8 \mathrm{~mm}$. Color shiny black everywhere (Figs. 56-57) except basomedian pronotal lobe, elytra, and pygidium, which are dull black (almost with a "bloom"). Head: Surface glabrous, with large, dense, glabrous punctures. Clypeus (dorsal view) nearly square, lateral margins constricted inwards at base, apex truncate with apical rim narrowly reflexed. Eyes large, interocular width equals 2.5 transverse eye diameters. Antenna with 10 antennomeres, club slightly longer than antennomeres 2-7. Pronotum: Surface glabrous with large, moderately dense punctures. Sides with thick marginal bead. Elytra: Surface with distinct rows of large, glabrous, ocellate, u-shaped, round, or irregularly shaped punctures and elevated sutural costa and 2 elevated costae on disc. Discal costae parallel, terminating at prominent apical umbone; sutural costa distinct for its entire length. Surface behind and mesad of apical umbone rugose. Apices 

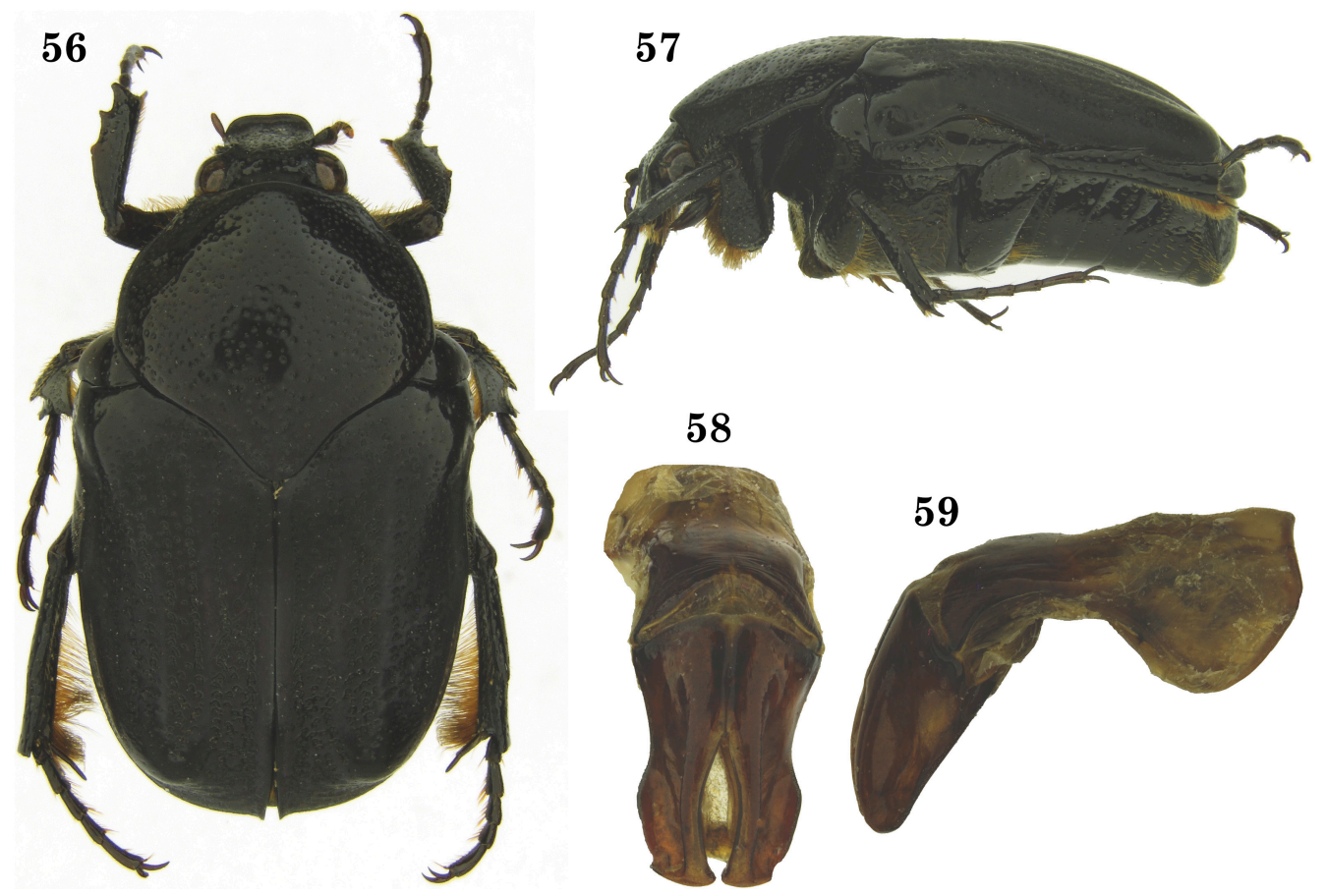

58
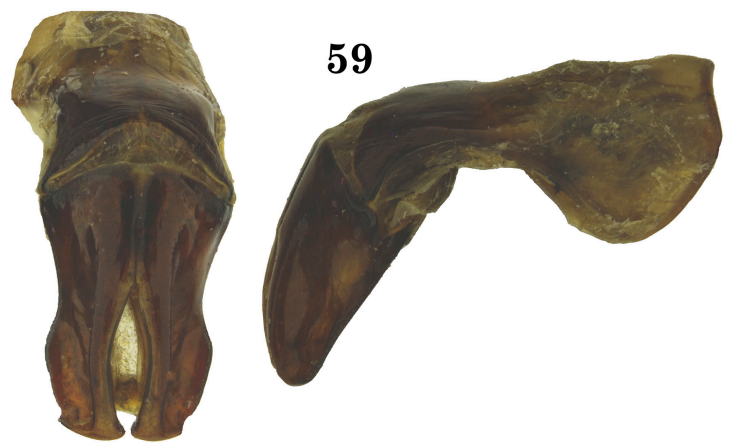

Figs. 56-59. Madiana brigitteae. 56-57) Holotype, dorsal and lateral habitus, respectively; 58-59) Parameres, caudal and lateral views, respectively.

at suture quadrate. Pygidium: Surface with large, moderately dense, setigerous, transverse strigae; setae minute, pale. Profile weakly convex in lateral view. Venter: Setae tawny. Mesometasternal process (lateral view) short, bulbous, broadly rounded, slightly protruding obliquely from ventral plane of body (Fig. 57); apex (ventral view) broadly rounded. Abdominal sternites nearly smooth on central third, lateral thirds with punctures moderate in size and density. Legs: Protibia tridentate, teeth subequally spaced from one another. Parameres: Form subrectangular in caudal view, flared on lateral edge at mid-shaft, with small, laterally projecting angle (almost a tooth) just before apices, apices rounded (Figs. 58-59).

Allotype. Female. Length $17.0 \mathrm{~mm}$; width across humeri $9.9 \mathrm{~mm}$. As holotype except in the following respects: Head: Interocular width equals 2.0 transverse eye diameters. Pygidium: Surface completely, concentrically rugose. Legs: Protibia tridentate, basal tooth removed from other teeth. The allotype is severely broken and in several pieces.

Etymology. This species is named in honor of Brigitte Romé, co-collector of the type specimens of this new species and spouse of Daniel.

Distribution. Madiana brigitteae is known only from the island of Martinique in the Lesser Antilles.
Locality Records. MARTINIQUE (2): Montagne du Vauclin (Fig. 60).

Temporal Distribution. March (2).

Natural History. Martinique is a composite of four originally separate volcanic cones that now comprise a single island but only since the late Pliocene or Pleistocene (Bouysse et al. 1985; Maury et al. 1990). Martinique is surrounded by deep oceanic waters and never had a dry land connection

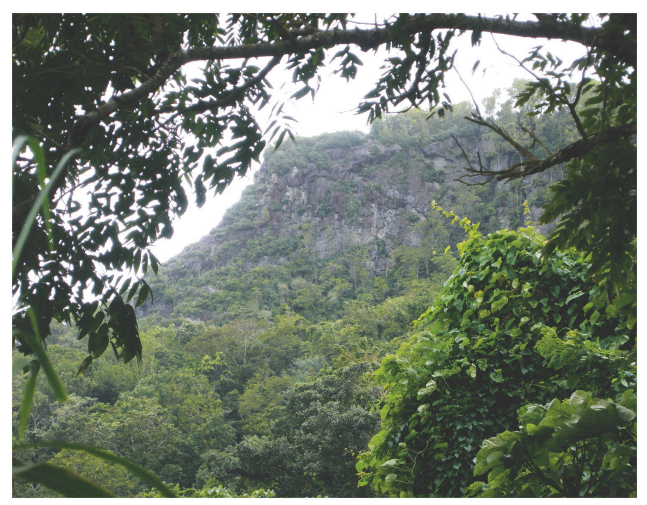

Fig. 60. Montagne du Vauclin, Martinique, type locality for Madiana brigitteae. 
to other islands, even during the Pleistocene when there was a sea-level depression of $130 \mathrm{~m}$ (Donnelly 1988; Hedges 2001; Clark et al. 2009). Most biotic colonization occurred during the past three million years by overwater dispersal (Peck 2011), and pioneering organisms then maintained themselves or evolved in isolation.

The male holotype was found in a rotting tree trunk, and the female paratype was found in a tree stump (300 m elevation), thus suggesting that the larvae probably complete their life cycle in dead and decaying wood. Mount Vauclin (Fig. 60) is an old volcano that rises $504 \mathrm{~m}$ in elevation and covers 56 hectares. It is isolated in southern Martinique near the village of Le Vauclin. The mesophyllic forest on its slopes is stratified into different zones as a result of increasing elevation that influences temperature and rainfall. A number of endemic and rare plants are found here, which reflects their geographic isolation. Madiana brigitteae is an insect example of evolution in isolation resulting in a unique organism.

\section{Checklist of the New World Gymnetini}

Allorrhina Burmeister, 1842 [last revision: Ratcliffe 2015a]

Allorrhina carmelita (Burmeister, 1842)

Cotinis carmelita Burmeister, 1842

Cotinis amazonica Thomson, 1857

Cotinis brasiliensis Kraatz, 1898

Allorrhina cincta (Gory and Percheron, 1833) Gymnetis cincta Gory and Percheron, 1833

Gymnetis cincta versicolor Moser, 1908

Allorrhina denotata Abadie and Ratcliffe, 2015a

Allorrhina menetriesii (Mannerheim, 1829)

(Figs. 2-3)

Gymnetis menetriesii Mannerheim, 1829

Gymnetis rhinoceros Gory and Percheron, 1833

Gymnetis cornifrons Gory and Percheron, 1833

Gymnetis episcopalis Gory and Percheron, 1833

Allorrhina baeri Bourgoin, 1911a

Allorrhina gounellei Bourgoin, 1911b

Allorrhina nickerli Moser, 1911a

Allorrhina nigerrima (Burmeister, 1842)

Cotinis nigerrima Burmeister, 1842

Gymnetis lugubris Thomson, 1878

Allorrhina scabriuscula (Swederus, 1787) (Fig. 1)

Cetonia scabriuscula Swederus, 1787

Gymnetis concolor Gory and Percheron, 1833

Allorrhina soror Moser, 1911b

Allorrhina tridentata Moser, 1908

Amithao Thomson, 1878 [last revision: Ratcliffe 2013a]

Melisictes Thomson, 1880

Hologymnia Schoch, 1895

Amithao albopictus Neervoort van der Poll, 1886b
Amithao anthracinus Ratcliffe, 2013 (Figs. 4-5)

Amithao cavifrons (Burmeister, 1842)

Cotinis cavifrons Burmeister, 1842

Amithao cotopaxicus Ratcliffe, 2017

Amithao decemguttatus (Waterhouse, 1876)

Gymnetis decemguttata Waterhouse, 1876

Amithao decemguttatus beinlingi Nonfried, 1894

Amithao erythropus (Burmeister, 1842)

Cotinis erythropus Burmeister, 1842

Cotinis moreleti Blanchard, 1850

Amithao splendens Nonfried, 1894

Desicasta nonfriedi Schoch, 1896a

Amithao erici Mitter, 2007

Amithao haematopus (Schaum, 1848) (Fig. 6)

Stethodesma haematopus Schaum, 1848

Amithao thomsoni (Janson, 1878)

Amithao incertus (Gory and Percheron, 1833) Gymmnetis incerta Gory and Percheron, 1833

Amithao lafertei (Thomson, 1860)

Cotinis lafertei Thomson, 1860

Amithao niveosparsus Moser, 1913

Amithao sparsus Casey, 1915

Amithao marginicollis (Burmeister, 1842) (Fig. 8)

Gymnetis marginicollis Burmeister, 1842

Clinteria undulata Schoch, 1895

Amithao metallicus (Janson, 1885)

Desicasta metallica Janson, 1885

Amithao pyrrhonotus (Burmeister, 1842)

Gymnetis pyrrhonota Burmeister, 1842

Amithao staudingeri Schürhoff, 1935

Amithao tristis (Fabricius, 1775) (Fig. 7)

Cetonia tristis Fabricius, 1775

Amithao spence (Gory and Percheron, 1833)

Argyripa Thomson, 1878 [last revision/synopsis:

Ratcliffe 1978; Arnaud 1988]

Argyripa anomala (Bates, 1872) (Fig. 9)

Allorhina anomala Bates, 1872

Argyripa lansbergei (Sallé, 1857)

Allorhina lansbergei Sallé, 1857

Allorhina hypoglauca Westwood, 1874

Argyripa moroni Arnaud, 1988

Argyripa porioni Arnaud, 1988

Argyripa subfasciata Ritsema, 1885 (Fig. 10)

Argyripa subfasciata purpurascens Schoch, 1897

Astroscara Schürhoff, 1937 [last synopsis: Ratcliffe 2014b]

Astroscara flavoradiata (Moser, 1918) (Fig. 11)

Gymnetis flavoradiata Moser, 1918

Badelina Thomson, 1880 [last revision: Ratcliffe 2014a]

Badelina aterrima (Gory and Percheron, 1833)

Gymnetis aterrima Gory and Percheron, 1833

Badelina pygidialis (Thomson, 1878) (Fig. 12) Gymnetis pygidialis Thomson, 1878 
Balsameda Thomson, 1880 [last revision: Ratcliffe 2014a])

Balsameda adspersa (Sharp, 1877)

Cotinis adspersa Sharp, 1877

Balsameda monzoni Ratcliffe, 2014a

Balsameda porioni Ratcliffe, 2014a

Balsameda pulverulenta (Burmeister, 1842) (Figs. 13-14)

Cotinis pulverulenta Burmeister, 1842

Cotinis gracilis Sharp, 1877

Gymnetis auropicta Nonfried, 1891

Blaesia Burmeister, 1842 [last synopsis: Ratcliffe 2010]

Blaesia atra Burmeister, 1842 (Figs. 15-17)

Blaesia subrugosa Moser, 1905

Chiriquibia Bates, 1889 [last synopsis: Ratcliffe 2014b]

Chiriquibia insignis (Janson, 1888) (Figs. 18-19) Allorhina insignis Janson, 1888

Cotinis Burmeister, 1842 [last revision/synopsis: Goodrich 1966; Gasca-Álvarez and Deloya 2015; Gasca-Álvarez 2017]

Latemnis Thomson, 1880

Cotinorrhina Schoch, 1895

Cotinis aliena Woodruff, 2008

Cotinis antonii Dugés, 1878

Cotinis senex Janson, 1880

Cotinis barthelemyi (Gory and Percheron, 1833) Gymnetis barthelemyi Gory and Percheron, 1833

Cotinis beraudi Delgado, 1998

Cotinis boylei Goodrich, 1966

Cotinis columbica Burmeister, 1842

Cotinis fuscopicea Goodrich, 1966

Cotinis ibarrai Deloya and Ratcliffe, 1988

Cotinis impia (Fall, 1905)

Gymnetis impia Fall, 1905

Cotinis laticornis Bates, 1889

Cotinis latifrons Schoch, 1895

Cotinis lebasi (Gory and Percheron, 1833)

Gymnetis lebasi Gory and Percheron, 1833

Cotinis lebasi panamensis Casey, 1915

Cotinis mutabilis (Gory and Percheron, 1833)

(Figs. 20-21)

Gymnetis mutabilis Gory and Percheron, 1833

Gymnetis atrata Gory and Percheron, 1833

Gymnetis nigrobrunnea Gory and Percheron, 1833

Gymnetis mexicana Gory and Percheron, 1833

Gymnetis palliata Gory and Percheron, 1833

Cotinis sobrina Gory and Percheron, 1833

Cotinis malinus Janson, 1880

Cotinis mutabilis var. aurantiaca Bates, 1889

Cotinis mutabilis var. cuprascens Bates, 1889

Cotinis mutabilis var. cuprascenti Bates, 1889

Cotinis mutabilis var. intergenea Bates, 1889
Cotinis mutabilis var. robusta Bates, 1889

Cotinis mutabilis var. subcastanea Bates, 1889

Cotinis sobrina var. schafraneki Nonfried, 1894

Cotinis mutabilis var. atra Kraatz, 1898

Cotinis mutabilis var. atropurpurea Kraatz, 1898

Cotinis mutabilis var. cuprea Kraatz, 1898

Cotinis mutabilis var. nigrovariegata Kraatz, 1898

Cotinis abdominalis abdominalis Casey, 1915

Cotinis abdominalis discolor Casey, 1915

Cotinis arizonica Casey, 1915

Cotinis capito Casey, 1915

Cotinis mutabilis ovicornuta Casey, 1915

Cotinis mutabilis var. piciventris Kraatz, 1898

Cotinis obliqua obliqua Casey, 1915

Cotinis obliqua coahuilae Casey, 1915

Cotinis obliqua commiscens Casey, 1915

Cotinis obliqua viridacauda Casey, 1915

Cotinis texana Casey, 1915

Cotinis lemoulti Antoine, 2007

Cotinis nitida (Linnaeus, 1764)

Scarabaeus nitidus Linnaeus, 1764

Cotinis angustula Casey, 1915

Cotinis debiliceps Casey, 1915

Cotinis longitarsis Casey, 1915

Cotinis longitarsis seriella Casey, 1915

Cotinis longula Casey, 1915

Cotinis nitida ornata Casey, 1915

Cotinis nitida pygidialis Casey, 1915

Cotinis nitida tibialis Casey, 1915

Cotinis parvula Casey, 1915

Cotinis nitida brunnea Hatch, 1930

Cotinis olivia Bates, 1889

Cotinis orientalis Deloya and Ratcliffe, 1988

Cotinis patricialvarezae Gasca-Álvarez and Deloya, 2015a

Cotinis pauperula Burmeister, 1847

Cotinis pokornyi Deloya, 1995

Cotinis polita Janson, 1876

Cotinis producta Bates, 1889

Cotinis pueblensis Bates, 1889

Cotinis punctatostriata Bates, 1889

Cotinis rufipennis Bates, 1889

Cotinis sinitoc Deloya, Ibáñez-Bernal, and Nogueira, 2000

Cotinis sphyracera Deloya and Ratcliffe, 1988

Cotinis subviolacea (Gory and Percheron, 1833) Gymnetis subviolacea Gory and Percheron, 1833

Cotinis plicatipennis Blanchard, 1850

Cotinis viridicyanea (Perbosc, 1839)

Gymnetis viridicyanea Perbosc, 1839

Desicasta Thomson, 1878 [last revision: Ratcliffe 2013b]

Moscheuma Thomson, 1880 
Desicasta lobata (Olivier, 1789) (Fig. 23)

Cetonia lobata Olivier, 1789

Cetonia coracina Herbst, 1790

Desicasta sculptilis Thomson, 1878

Moscheuma sebosa Neervoort van de Poll, $1886 \mathrm{~b}$

Moscheuma opaca Kraatz, 1898

Desicasta purpurascens (Schoch, 1898)

Moscheuma purpurascens Schoch, 1898

Desicasta reichei (Thomson, 1860) (Fig. 22)

Stethodesma reichei Thomson, 1860

Moscheuma laevicostata Neervoort van de Poll, 1886b

Guatemalica Neervoort van de Poll, 1886a [last synopsis: Ratcliffe 2014a]

Guatemalica fuliginosa (Nonfried, 1894) Gymnetis fuliginosa Nonfried, 1894

Guatemalica hueti (Chevrolat, 1870) (Figs. 24-25)

Allorrhina hueti Chevrolat, 1870

Gymnephoria Ratcliffe, 2019

Gymnephoria spilota Ratcliffe, 2019 (Figs. 26, 53-55)

Gymnetina Casey, 1915 [last revision: Ratcliffe and Warner 2011]

Gymnetina alboscripta (Janson, 1878) Gymnetis alboscripta Janson, 1878

Gymnetina borealis Warner and Ratcliffe, 2011

Gymnetina cretacea cretacea (LeConte, 1863) (Fig. 27)

Gymnetis cretacea LeConte, 1863

Gymnetina cretacea sundbergi Warner and Ratcliffe, 2011

Gymnetina grossepunctata Ratcliffe and Warner, 2011

Gymnetina howdeni Warner and Ratcliffe, 2011

Gymnetina salicis (Bates, 1889)

Cotinis salicis Bates, 1889

Amithao distigma Schoch, 1898

Gymnetis MacLeay, 1819 [last revision: Ratcliffe 2018]

Gymnetis albomaculata Blanchard, 1850

Gymnetis amazona Ratcliffe, 2018

Gymnetis aurantivittae Ratcliffe, 2018

Gymnetis aureotorquata Bourgoin, 1912 Gymnetis luctuosa Bourgoin, 1916

Gymnetis bajula bajula (Olivier, 1789)

Cetonia bajula Olivier, 1789

Gymnetis perplexa Dejean, 1833, nomen nudum

Gymnetis glauca Gory and Percheron, 1833

Gymnetis perplexa Burmeister, 1842

Gymnetis vermiculea Burmeister, 1842

Gymnetis banghaasi Schürhoff, 1937
Gymnetis bajula wollastonii Schaum, 1848

Gymnetis balzarica Janson, 1880

Gymnetis bomplandi Schaum, 1844

Gymnetis bouvieri Bourgoin, 1912

Gymnetis bruchi Moser, 1910

Aemilus wagneri Le Moult, 1939

Gymnetis buckleyi (Janson, 1879) (Fig. 28)

Cetonia buckleyi Janson, 1879

Gymnetis carbo (Schürhoff, 1937)

Paragymnetis carbo Schürhoff, 1937

Gymnetis cerdai Antoine, 2001

Gymnetis chalcipes Gory and Percheron, 1833 Scarabaeus tonkaea Voet, 1779, nomen nudum Gymnetis irregularis Gory and Percheron, 1833

Gymnetis similis Gory and Percheron, 1833

Gymnetis chevrolati Gory and Percheron, 1833 Gymnetis catharinae Schürhoff, 1937

Gymnetis cordobana Schürhoff, 1937

Gymnetis coturnix Burmeister, 1842

Gymnetis chontalensis Janson, 1875

Gymnetis nigrina Bates, 1889

Gymnetis cupriventris cupriventris Janson, 1880

Gymnetis cupriventris kerremansi Neervoort van de Poll, 1886b

Gymnetis guntheri Schürhoff, 1937

Gymnetis difficilis Burmeister, 1842

Gymnetis drogoni Ratcliffe, 2018

Gymnetis flava (Weber, 1801)

Cetonia flava Weber, 1801

Gymnetis cincta Perty, 1830

Gymnetis pallidipennis Blanchard, 1850

Gymnetis limbolaniata Pouillaude, 1913

Gymnetis flaveola (Fabricius, 1801) (Fig. 29)

Cetonia flaveola Fabricius, 1801

Gymnetis shistacea Burmeister, 1847

Gymnetis batesii Thomson, 1857

Gymnetis scapularis Janson, 1880

Gymnetis waehneri Schürhoff, 1937

Gymnetis flavinotis Schürhoff, 1937

Gymnetis flavocincta Bates, 1891

Gymnetis bogotensis Pouillaude, 1913

Gymnetis limbata Pouillaude, 1913

Gymnetis ecuadoriensis Pouillaude, 1913

Gymnetis flavomarginata Blanchard, 1842 (Fig. 30)

Gymnetis goryi Janson, 1877 (Fig. 31)

Gymnetis guadalupiensis Gory and Percheron, 1833

Gymnetis hebraica (Drapiez, 1820)

Cetonia hebraica Drapiez, 1820

Gymnetis depauperata Gory and Percheron, 1833

Gymnetis hepatica Di Iorio, 2013

Gymnetis hieroglyphica Vigors, 1825

Gymnetis holosericea (Olivier, 1789) (Fig. 32)

Scarabaeus holosericus Voet, 1779, nomen nudum 
Cetonia holosericea Olivier, 1789

Cetonia circumdata Schönherr, 1817

Gymnetis magnifica Gory and Percheron, 1833

Gymnetis sexmaculata Blanchard, 1850

Gymnetis xanthospila Schaum, 1844

Gymnetis mathani Pouillaude, 1913

Gymnetis olivina Pouillaude, 1913

Gymnetis distincta Pouillaude, 1913

Gymnetis chanchamayensis Pouillaude, 1913

Gymnetis immunda Schaum, 1844

Gymnetis lanius (Linnaeus, 1767)

Scarabaeus lanius Linnaeus, 1767

Scarabaeus pullus Voet, 1779, nomen nudum

Gymnetis litigiosa Gory and Percheron, 1833

Gymnetis inquinata Thomson, 1878

Gymnetis margineguttata Gory and Percheron, 1833

Gymnetis schaueri Schürhoff, 1937

Gymnetis scheini Schürhoff, 1937

Gymnetis marmorea (Olivier, 1789)

Scarabaeus pulcher Swederus, 1787, nomen oblitum

Cetonia marmorea Olivier, 1789

Cetonia tristis Olivier, 1789

Cetonia picta Olivier, 1789

Gymnetis dysoni White, 1847, nec Schaum 1848

Gymnetis nigricollis Kraatz, 1888

Gymnetis merops Ratcliffe, 2018

Gymnetis pantherina Blanchard, 1842

Gymnetis alauda Burmeister, 1842

Gymnetis meleagris Burmeister, 1842

Gymnetis lyncea Erichson, 1847

Gymnetis lutulenta Kirsch, 1870

Gymnetis pelochroma Kirsch, 1873

Gymnetis fabaria Janson, 1880

Gymnetis granadensis Kraatz, 1888

Gymnetis candida Kraatz, 1888

Gymnetis pallescens Kraatz, 1888

Gymnetis zikani Moser, 1921

Paragymnetis rubrocincta Schürhoff, 1937

Gymnetis pardalis Gory and Percheron, 1883 Gymnetis crypturus Burmeister, 1842

Gymnetis phasianus Burmeister, 1842

Gymnetis poecila Schaum, 1848

Gymnetis pudibunda Burmeister, 1866 Gymnetis pudibunda var. porteri Dallas, 1930

Gymnetis puertoricensis Ratcliffe, 2018

Gymnetis punctipennis Burmeister, 1844 Gymnetis cervina Schaum, 1845, nomen nudum Paragymnetis theresana Schürhoff, 1937

Gymnetis radiicollis Burmeister, 1847 Gymnetis radiosicollis Schürhoff, 1937

Gymnetis ramulosa Bates, 1872 (1869)

Gymnetis radicula Schoch, $1896 \mathrm{~b}$

Gymnetis ramifera Schaeffer, 1905

Gymnetis colombiana Pouillaude, 1913

Gymnetis balteata Casey, 1915
Gymnetis rhaegali Ratcliffe, 2018

Gymnetis rudolphi (Frölich, 1792)

Cetonia rudolphi Frölich, 1792

Gymnetis luciae Blanchard, 1850, nomen nudum

Gymnetis rufilatris (Illiger, 1800)

Cetonia rufilatris Illiger, 1800

Gymnetis sallei Schaum, 1849 [not 1843]

Gymnetis callispila Bates, 1889

Gymnetis stellata (Latreille, 1813)

Cetonia stellata Latreille, 1813

Macronota radiata Wiedemann, 1824

Gymnetis sternalis Chevrolat, 1865

Gymnetis strigosa (Olivier, 1789)

Scarabaeus histrio ruber Voet, 1779, nomen nudum

Cetonia strigosa Olivier, 1789

Gymnetis fulgurata Gory and Percheron, 1833

Gymnetis mediana Kraatz, 1888

Gymnetis subpunctata Westwood, 1874

Gymnetis dispersa Janson, 1880

Gymnetis discolor Janson, 1880

Gymnetis variabilis Moser, 1921

Gymnetis kuntzeni Schürhoff, 1937

Gymnetis thula Ratcliffe, 2018

Gymnetis undata (Olivier, 1789)

Cetonia undata Olivier, 1789

Macronota geographica Sturm, 1826, nomen nudum

Gymnetis similis Burmeister, 1843 [published as a synonym]

Paragymnetis burmeisteri Schürhoff, 1937

Gymnetis vandepolli Bates, 1889

Gymnetis viserioni Ratcliffe, 2018

Hadrosticta Kraatz, 1892 [last synopsis: Ratcliffe 2014b]

Hadrosticta viridiflua Kraatz, 1892 (Fig. 33)

Halffterinetis Morón and Nogueira, 2007 [last synopsis: Ratcliffe 2010]

Halffterinetis gonzaloi Morón and Nogueira, 2007 (Fig. 34)

Halffterinetis violetae Morón and Nogueira, 2007

Heterocotinis Martínez, 1948 [last synopsis: Ratcliffe 2014a]

Heterocotinis semiopaca (Moser, 1907) (Fig. 35) Cotinis semiopaca Moser, 1907

Gymnetis platensis Brèthes, 1925

Gymnetis platensis var. tandilensis Brèthes, 1925

Heterocotinis terminata (Gory and Percheron, 1833) (Fig. 36)

Gymnetis terminata Gory and Percheron, 1833 Gymnetis smaragdinea Gory and Percheron, 1833

Gymnetis klugi Gory and Percheron, 1833

Cotinis nitidicollis Moser, 1907 
Hologymnetis Martínez, 1949 [last revision/synopsis: Ratcliffe and Deloya 1992; Gasca and Deloya 2015]

Cineretis Krikken, 1984

Hologymnetis argenteola (Bates, 1889) Gymnetis argenteola Bates, 1889

Gymnetis argenteola laetula Casey, 1915

Hologymnetis cinerea (Gory and Percheron, 1833) (Figs. 37-38)

Gymnetis cinerea Gory and Percheron, 1833

Gymnetis punctata Blanchard, 1850

Gymnetis uniformis Blanchard, 1850

Gymnetis cuneata Casey, 1915

Gymnetis lobiculata Casey, 1915

Gymnetis simulans Casey, 1915

Gymnetis aequalis Casey, 1915

Hologymnetis kinichahau Ratcliffe and Deloya, 1992

Hologymnetis margaritis (Bates, 1889) Gymnetis margaritis Bates, 1889

Hologymnetis moroni Ratcliffe and Deloya, 1992

Hologymnetis reyesi Gasca-Álvarez and Deloya, 2015b

Hologymnetis undulata (Vigors, 1825)

Cetonia undulata Vigors, 1825

Gymnetis consularis Gory and Percheron, 1833

Hologymnetis vulcanorum Ratcliffe and Deloya, 1992

Hoplopyga Thomson, 1880 [last revision: Shaughney and Ratcliffe 2015]

Hoplopyga aequatorialis (Moser, 1918) Gymnetis aequatorialis Moser, 1918

Hoplopyga albiventris (Gory and Percheron, 1833)

Gymnetis albiventris Gory and Percheron, 1833

Gymnetis fuscorubra Gory and Percheron, 1833

Hoplopyga antilliana Ratcliffe, 2012

Hoplopyga boliviensis (Moser, 1918) Gymnetis boliviensis Moser, 1918

Hoplopyga brasiliensis (Gory and Percheron, 1833)

Gymnetis brasiliensis Gory and Percheron, 1833 Gymnetis prothoracica Thomson, 1878

Hoplopyga cerdani Antoine, 1998

Hoplopyga foeda (Schaum, 1848) Gymnetis foeda Schaum, 1848

Gymnetis lucidiventris Thomson, 1878

Hoplopyga gosseti Antoine, 2008

Hoplopyga liturata (Olivier, 1789) (Fig. 39)

Scarabaeus pennicrusta Voet, 1776, nomen nudum

Cetonia liturata Olivier, 1789

Gymnetis spinosa Fischer von Waldheim, 1823

Gymnetis hamata Fauvel, 1860

Gymnetis spurca Janson, 1880
Hoplopyga marginesignata (Gory and Percheron, 1833)

Gymnetis marginesignata Gory and Percheron, 1833

Gymnetis fumata Janson, 1880

Hoplopyga miliaris (Gory and Percheron, 1833)

Gymnetis miliaris Gory and Percheron, 1833

Gymnetis fodina Gory and Percheron, 1833

Gymnetis suasa Gory and Percheron, 1833

Hoplopyga miniata (Blanchard, 1847)

Gymnetis miniata Blanchard, 1847

Hoplopyga multipunctata (Gory and Percheron, 1833)

Gymnetis multipunctata Gory and Percheron, 1833

Holopyga [sic] multiguttata Schoch, 1895

Hoplopyga ocellata (Gory and Percheron, 1833) Gymnetis ocellata Gory and Percheron, 1833

Hoplopyga peruana (Moser, 1912)

Gymnetis peruana Moser, 1912

Hoplopyga pseudomiliaris Shaughney and Ratcliffe, 2015

Hoplopyga ravida (Janson, 1881)

Gymnetis ravida Janson, 1881

Hoplopyga riparia Shaughney and Ratcliffe, 2015

Hoplopyga sculptiventris (Thomson, 1878), incertae sedis, possibly melanistic $H$. boliviensis Gymnetis sculptiventris Thomson, 1878

Hoplopyga singularis (Gory and Percheron, 1833)

Gymnetis singularis Gory and Percheron, 1833

Gymnetis monacha Gory and Percheron, 1833

Gymnetis rubida Gory and Percheron, 1833

Hoplopyga corumbana Schürhoff, 1942

Hoplopyga suilla (Janson, 1881)

Gymnetis suilla Janson, 1881

Hoplopygothrix Schürhoff, 1933 [last revision:

Ratcliffe 2005, 2011]

Hoplopygothrix atropurpurea (Schaum, 1841)

(Figs. 40-41)

Gymnetis atropurpurea Schaum, 1841

Gymnetis fulvohirta Moser, 1910

Gymnetis atropurpurea nigroscutellaris Moser, 1910

Gymnetis rugosa Bourgoin, 1916

Hoplopygothrix boliviensis Ratcliffe, 2011

Howdenypa Arnaud, 1993 [last revision/synopsis:

Ratcliffe 1978; Arnaud 1988, 1993]

Howdenia Arnaud, 1988 (preoccupied)

Howdenypa gloriosa (Ratcliffe, 1978) (Fig. 42) Argyripa gloriosa Ratcliffe, 1978

Jansonia Schürhoff, 1937 [last synopsis: Ratcliffe 2014b] 
Jansonella Blackwelder, 1944

Jansonia anceps (Janson, 1875) (Fig. 43)

Gymnetis anceps Janson, 1875

Macrocranius Schürhoff, 1935 [last synopsis: Ratcliffe 2014b]

Macrocranius similis Schürhoff, 1935 (Figs. 44-45)

Madiana Ratcliffe and Romé, 2019

Madiana brigitteae Ratcliffe and Romé, 2019 (Figs. 46, 56-59)

Marmarina Kirby, 1827 [last revision: Ratcliffe 2015b]

Maculinetis Schürhoff, 1937

Marmarina argentina (Moser, 1917) (Fig. 47)

Gymnetis argentina Moser, 1917

Marmarina insculpta (Kirby, 1819) (Fig. 48)

Cetonia insculpta Kirby, 1819

Cetonia margaratacea Germar, 1824

Cetonia scutellata Perty, 1830

Marmarina nigrorubra Schürhoff, 1937

Marmarina maculosa (Olivier, 1789)

Cetonia maculosa Olivier, 1789

Cetonia irrorata Olivier, 1789

Cetonia graculus Fabricius, 1792

Gymnetis apiata Burmeister, 1842

Gymnetis punctatisssima Burmeister, 1842

Gymnetis meticulosa Thomson, 1878

Gymnetis submaculosa Thomson, 1878

Marmarina parvula Ratcliffe, 2015

Marmarina tigrina (Gory and Percheron, 1833) (Fig. 49)

Gymnetis tigrina Gory and Percheron, 1833

Gymnetis albosparsa Blanchard, 1847

Gymnetis touchardi Blanchard, 1847

Gymnetis strobeli Burmeister, 1866

Marmarina litorea Schürhoff, 1937

Neocorvicoana Ratcliffe and Micó, 2001 [last revision: Ratcliffe and Micó 2001] Heteropodia Schürhoff, 1933, nomen nudum Corvicoana Strand, 1934, nomen nudum Heteropodetis Schürhoff, 1937, nomen nudum

Neocorvicoana chalybea (Blanchard, 1850) Gymnetis chalybea Blanchard, 1850

Heteropodia suavis Schürhoff, 1933

Heteropodia castanea Schürhoff, 1933

Neocorvicoana reticulata (Kirby, 1818) (Figs. 50-51)

Cetonia reticulata Kirby, 1818

Gymnetis anoguttata Gory and Percheron, 1833

Gymnetis carbonaria Gory and Percheron, 1833

Gymnetis varia Gory and Percheron, 1833

Neocorvicoana tricolor Schürhoff, 1933

Tiarocera Burmeister, 1842 [last synopsis: Ratcliffe 2014b]
Tiarocera cornuta (Gory and Percheron, 1833)

(Fig. 52)

Gymnetis cornuta Gory and Percheron, 1833

\section{ACKNOWLEDGMents}

I gratefully acknowledge the many curators and collection managers who gave their assistance to the project over the years by hosting me at their institutions and/or by providing specimens on loan. I deeply appreciate those who permitted me to grossly overextend my loans of specimens, an unanticipated consequence and necessary evil for a project of this magnitude. A list of these generous people can be found in the Acknowledgments section of each of my generic synopses.

For the description of $M$. brigitteae, Daniel Romé and I thank Julien Touroult (Museum National d'Histoire Naturelle, Paris, France) for his recommendations and advice and Francis Deknuydt (Les Trois-Îlets, Martinique) for additional information about the forest on Martinique (Zone Naturelle d'intérêt Ecologique Floristique et Faunistique).

\section{References Cited}

Antoine, P. 1998. Quelques espèces nouvelles ou peu connues de la famille des Cetoniidae VI (Coleoptera, Cetoniidae). Coléoptères 4: 65-84.

Antoine, P. 2001. Contribution à la connaissance des Gymnetini (Coleoptera, Cetoniidae). Coléoptères 7: $113-136$

Antoine, P. 2007. Un nouveau Cotinis Burmeister, 1842, du Panama (Coleoptera, Cetoniidae). Coléoptères 13: 47-50.

Antoine, P. 2008. Contribution à la connaissance du genre Hoplopyga J. Thomson (Coleoptera, Cetoniidae). Coléoptères 14: 241-256.

Arnaud, P. 1988. Les especes du genre Argyripa Thomson (Col. Cetoniinae). Sciences Nat 57: 25-28.

Arnaud, P. 1993. Note rectificative. Sciences Nat 78: 28.

Bates, H. W. 1872 [1869]. New species of Coleoptera from Chontales, Nicaragua. Transactions of the Entomological Society of London 1869: 383-389.

Bates, H. W. 1889. Fam. Dynastidae (continued), Fam. Cetoniidae, Supplement [pp. 337-416]. In: Biologia Centrali-Americana. Insecta, Coleoptera. Volume 2, Part 2 (F. D. Godman and O. Salvin, editors). Taylor and Francis, London, UK.

Bates, H. W. 1891. Coleoptera [pp. 7-39]. In: Supplementary Appendix to Travels Amongst the Great Andes of the Equator (E. Whymper, editor). John Murray, London, UK.

Blackwelder, R. E. 1944. Checklist of the coleopterous insects of Mexico, Central America, the West Indies, and South America, part 2. Bulletin of the United States National Museum 185: 189-341.

Blanchard, E. 1842. Voyage dans l'Amerique Méridionale (le Brésil, la République Orientale de l'Uruguay, la République du Chili, la République de Bolivia, la 
République du Pérou), Exécuté Pendant les Années $1826,1827,1828,1829,1830,1831,1832$ et 1833 , par Alcide d'Orbignay. Volume 6, Part 2 (Insectes). Plates 11-12. Paris, France.

Blanchard, E. 1847. Famille des Cétoniens [pp. 193-194]. In: Voyage dans l'Amerique Méridionale (le Brésil, la République Orientale de l'Uruguay, la République du Chili, la République de Bolivia, la République du Pérou), Exécuté Pendant les Années 1826, 1827, 1828, 1829, 1830, 1831, 1832 et 1833, par Alcide d'Orbignay. Volume 6, Part 2 (Insectes) (E. Blanchard and E. Brullé, editors). Levrault, Paris, France.

Blanchard, E. 1850. Ordre des Coloptera. $1^{\text {re }}$ Famille Scarabaeidae. $1^{\text {re }}$ Tribu-Cetoniinae [pp. 1-51]. In: Museum d' Histoire Naturelle de Paris. Catalogue de la Collection Entomologique. Classe des Insectes. Ordre des Coleopteres, Tome 1 (H. Milne-Edwards, E. Blanchard, and H. Lucas, editors). Gide et Baudry, Paris, France.

Bourgoin, A. 1911a. Description de deux espéces nouvelles appartenant au genre Allorrhina (Col, Scarabaeidae). Bulletin de la Société Entomologique de France 1911: 133-135.

Bourgoin, A. 1911b. Description d'une espèce nouvelle du genre Allorrhina Burm. (Col, Scarabaeidae). Bulletin de la Société Entomologique de France 1911: 230-231.

Bourgoin, A. 1912. Description d'une espèce nouvelle du genre Gymnetis MacLeay (Col., Scarabaeidae). Bulletin de la Société Entomologique de France 1912: 42-44.

Bourgoin, A. 1916. Description de deux Gymnetis nouveaux du Brésil. Bulletin de la Société Entomologique de France 1916: 198-200.

Bouysse, P., D. Westercamp, P. Andreieff, J. C. Baubron, and G. Scholari. 1985. Le volcanisme sous-marin Néogène recent au large des côtes Caraibes des Antilles française. Relations avec le volcanisme à terre de évolution du front volcanique. Service Geologique National 1985 (Géologie de la France, Orleans, France): 101114.

Brèthes, J. 1925. Nouveaux coléoptères sudaméricains. Nunquam Otiosus 4: 11-16.

Burmeister, H. 1842. Handbuch der Entomologie, Volume 3. T.E.F. Enslin, Berlin, Germany.

Burmeister, H. 1844. Handbuch der Entomologie, Volume 4. T.E.F. Enslin, Berlin, Germany.

Burmeister, H. 1847. Handbuch der Entomologie, Volume 5. T.E.F. Enslin, Berlin, Germany.

Burmeister, D. G.[sic]. 1866. Coleópteros lamelicornes melitófilos de las provincias Argentinas. Revista del Sociedad de Farmacéutica de Argentina 1866: 573-577.

Casey, T. L. 1915. Memoirs on the Coleoptera 6: 1-394.

Chevrolat, A. 1865. Notes, synonymies et descriptions d'espèces nouvelles. Annales de la Société Entomologique de France (Series 4) 5: 21-36.

Chevrolat, A. 1870. Description de six coléoptères exotiques. Annales de la Société Entomologique de Belgique 14: 5-8.

Clark, P. U., A. S. Dyke, J. D. Shakun, A. E. Carlson, J. Clark, B. Wohlfarth, J. X. Mitrovica, S. W.
Hoestetler, and A. M. McCabe. 2009. The last glacial maximum. Science 325: 710-714.

Cornevin, R. 2018. Martinique. Overseas Department, France. Encyclopedia Britannica online. www. britannica.com/place/Martinique (accessed 24 April 2018).

Dallas, E. D. 1930. Gymnetis pudibunda Burm. var. porteri, nov. var. Revista Chilena de Historia Natural 34: $11-12$.

Dejean 1833. Catalogue de la collection de coléopteres de M. le Baron Dejean. Livraison 2, pp. 97-176. Méquignon-Marvis Père et Fils, Paris, France.

Delgado, L. 1998. A new Mexican species of Cotinis (Coleoptera, Melolonthidae). Revista Brasileira de Entomologia 41: 451-452.

Deloya, C. 1995. A new species of Cotinis (Cotinis) Burmeister from Mexico (Coleoptera: Melolonthidae, Cetoniinae) The Coleopterists Bulletin 49: 149-152.

Deloya, C., S. Ibáñez-Bernal, and G. Nogueira. 2000. A new species of Cotinis (Cotinis) (Coleoptera: Melolonthidae) and a key for the identification of Mexican species. Entomological News 111: $171-176$

Deloya, A. C., and B. C. Ratcliffe. 1988. A synopsis of the genus Cotinis in Mexico with description of three new species (Coleoptera: Scarabaeidae: Cetoniinae). Acta Zoológica Mexicana 28: 1-52.

Di Iorio, O. 2013. A review of the Cetoniinae (Coleoptera: Scarabaeidae) from Argentina and adjacent countries: Systematics and geographic distributions. Zootaxa 3668: 1-87.

Donnelly, T. W. 1988. Geologic constraints on Caribbean biogeography [pp. 15-37]. In: Zoogeography of Caribbean Insects (J. K. Liebherr, editor). Comstock Publishing Associates, Cornell University Press, Ithaca, NY.

Drapiez, P. A. J. 1820. Description de huit espèces d'insectes nouveaux. Annales Générales des Sciences Physiques 5: 117-123, plate 72.

Dugés, E. 1878. Descripción de coleópteros indígenos. La Naturaleza 4: 169-188.

Erichson, W. F. 1847. Conspectus insectorum coleopterorum quae in Republica Peruana observata sunt. Archiv für Naturgeschichte 13: 67-185.

Fabricius, J. C. 1775. Systema Entomologiae. Flensburg and Leipzig, Germany.

Fabricius, J. C. 1792. Entomologia Systematica, Volume 1, part 2. Copenhagen, Denmark.

Fabricius, C. 1801. Systema Eleutheratorum Secundum. Ordines, Genera, Species Adiectis Synonymis, Locis, Observationibus, Descriptionibus Tomus 1. Bibliopolii Academici Novi, Kiel, Germany.

Fall, H. C. 1905. New species of Coleoptera from the Southwest. The Canadian Entomologist 37: 270-276.

Fauvel, M. A. 1860. Catalogue des insectes recueillis a la Guyane Française par M. E. Déplanche, chirurgien auxiliaire de la marine impériale, pendant la campagne de l'aviso à vapeur le Rapide, années 1854-55-56. Bulletin de la Société Linnéenne de Normandie 5: 305-306.

Fischer von Waldheim, G. 1823. Coleoptera quaedam exotica descripta. Mémoires de la Société Naturalists de Moscou 6: 254-267. 
Frölich, J. A. 1792. Bermerkungen über einege seltene Käfer aus der Insecten-Sammlung des Hr. Rudolph in Erlangen. Naturforscher, Part 26: 68-165.

Gasca-Álvarez, H. J. 2017. El género americano Cotinis Burmeister (Coleoptera: Scarabaeidae: Cetoniinae): Morfología, taxonomía y relaciones filogenéticas. $\mathrm{PhD}$ dissertation, Instituto de Ecología A. C., Xalapa, Mexico.

Gasca-Álvarez, H. J., and C. Deloya. 2015a. A new species and first record of Cotinis Burmeister (Coleoptera: Scarabaeidae: Cetoniinae) for Venezuela. Zootaxa 3948: 125-136.

Gasca-Álvarez, H. J., and C. Deloya. 2015b. A new Mexican species of Hologymnetis Martínez (Coleoptera: Scarabaeidae: Cetoniinae: Gymnetini). Florida Entomologist 98: 100-103.

Germar, E. F. 1824. Insectorum Species. Novae aut Minus Cognmitae, Descriptionibus Illustratae. Volume 1. Coleoptera. Halle, Germany.

Goodrich, M. A. 1966. A revision of the genus Cotinis (Coleoptera: Scarabaeidae). Annals of the Entomological Society of America 59: 550-568.

Gory, H., and A. Percheron. 1833. Monographie des cétoines et genres voisins, formant, dans les familles naturelles de Latreille, la division des scarabées mélitophiles. J.-B. Baillière, Paris, France.

Hatch, M. H. 1930. Records and new species of Coleoptera from Oklahoma and western Arkansas, with subsidiary studies. Publications of the University of Oklahoma Biological Survey 2: 15-26.

Hedges, S. B. 2001. Biogeography of the West Indies: An overview [pp. 15-33]. In: Biogeography of the West Indies. Patterns and Perspectives, Second Edition (C. A. Woods and F. E. Sergile, editors). CRC Press, Boca Raton, FL.

Herbst, J. F. W. 1790. Cetonia. In: Jablonsky, C. G. Natursystem aller bekannten in- und ausländischen Insekten als eine Fortsezzung der von Büffonschen Naturgeschichte: Nach dem System des Ritters Carl von Linne bearbeitet von Carl Gustav Jablonsky, fortgesetzt von Johann Friedrich Wilhelm Herbst. Der Käfer dritter Theil. Mit sechzehn illuminirten Kupfertafeln (C. G. Jablonsky,). Joachim Pauli, Berlin, Germany.

Ibarra-Polesel, J. C. Neita-Moreno, D. D. Larrea, and M. P. Damborsky. 2017. Description of the larva and pupa of Neocorvicoana reticulata (Kirby, 1819) (Coleoptera: Scarabaeidae: Cetoniinae: Gymnetini). Zootaxa 4358: 430-440.

Illiger, K. 1800. Vierzig neue Insecten aus der Hellwigischen Sammlung in Braunschweig. Archiv für Zoologie und Zootomie 1: 103-150.

Janson, O. E. 1875. Description of three new species of American Cetoniidae. Cistula Entomologica 1: 373-376.

Janson, O. E. 1876. Notices of new or little known Cetoniidae, No. 1. Cistula Entomologica 2: 133-140.

Janson, E. O. 1877. Notices of new or little known Cetoniidae. No. 3. Cistula Entomologica 2: 247264.

Janson, O. E. 1878. Notices of new or little known Cetoniidae. No. 4. Cistula Entomologica 2: 299-304.

Janson, E. O. 1879. Notices of new or little known Cetoniidae. No. 6. Cistula Entomologica 2: 537-539.
Janson, O. E. 1880. Descriptions of new American Cetoniidae. Cistula Entomologica 2: 575-580.

Janson, O. E. 1881. Descriptions of new American Cetoniidae. Part II. Cistula Entomologica 2: 581-585.

Janson, O. E. 1885. Notices of new or little known Cetoniidae. No. 10. Cistula Entomologica 3: 139-152.

Janson, O. E. 1888. On the male sex of Argyripa subfasciata Rits., and description of a new species of the cetoniid genus Allorhina [sic]. Notes from the Leyden Museum 10: 118-120.

Kirby, W. 1819 (1818). A century of insects, including several new genera described from his cabinet. Transactions of the Linnaean Society of London 12: $375-453$.

Kirby, W. 1827. A description of some new genera and species of petalocerous Coleoptera. Zoological Journal 3: 145-158.

Kirsch, T. 1870. Beiträge zur Kenntniss Käferfauna von Bogotà. Berliner Entomologische Zeitschrift 14: 353-378.

Kirsch, T. 1873. Beiträge zur Kenntniss der Peruanischen Käferfauna auf Dr. Abendroth's Sammlungen basirt. Berliner Entomologische Zeitschrift 17: 339-418.

Kraatz, G. 1888. Ueber die sudamerikanische Gymnetis pantherina Burm. und die mit ihr verwechselten und verwandten Arten. Deutsche Entomologische Zeitschrift 32: 295-300.

Kraatz, G. 1892. Hadrosticta nov. gen. Cetonidarum aus Central Amerika, neben Argyripa lansbergii Sallé. Deutsche Entomologische Zeitschrift 36: 378-379.

Kraatz, G. 1898. Stenolomaptera nov. gen. Cetonidarum. Deutsche Entomologische Zeitschrift 1898: 95-96.

Kraatz, G. 1898. Bemerkungen zum Nachtrag VI von Schoch's "Genera und Species meiner CetonidenSammlung." Deutsche Entomologische Zeitschrift 1898: 217-224.

Krajčík, M. 1998. Cetoniidae of the World. Catalogue Part 1. Published by the author, Most, Czech Republic.

Krikken, J. 1984. A new key to the suprageneric taxa in the beetle family Cetoniidae, with annotated lists of the known genera. Zoologische Verhandelingen 210: 3-75.

Latreille, P. A. 1813. Insectes de l'Amérique Équinoxiale, Recueillis Pendant le Voyage de Mm. de Humboldt et Bonpland, et décrits, Seconde Partie [pp. 1-64]. In: Voyage de Humboldt et Bonpland. Deuxième Partie. Observations de Zoologie et Anatomie Comparée (A. Humboldt and A. J. A. G. Bonpland, editors). F. Schœll and Dufour, Paris, France.

Le Moult, E. 1939. Description d'un nouveau genre et d'une nouvelle espèce de Gymnetini (Coleop., Cetoninae) de la République Argentine. Noviates Entomologicae 10: 79-80.

LeConte, J. L. 1863. New species of North American Coleoptera. Part 1. Smithsonian Miscellaneous Collections 167: 1-92.

Linnaeus, C. 1764. Museum Ludoricae Ulricae Reginae Svecorum ... Stockholm, Sweden.

Linnaeus, C. 1767. Systema Naturae, Tome 1, Pars 2, Editio Duodecima Reformata. Stockholm, Sweden. 
MacLeay, W. S. 1819. Horae Entomologicae: or Essays on the Annulose Animals, Volume 1, Part 1. Printed for S. Bagster by Richard and Arthur Taylor, London, UK.

Mannerheim C. G. 1829. Description de quarante nouvelles espèces de scarabeides du Bresil. Nouveaux Memoires de la Société Imperiale des Naturalistes de Moscou 1(7): 29-80.

Martínez, A. 1948. Insectos nuevos o poco conocidos VI. (Col., Scarabaeidae) Revista de la Sociedad Entomologica Argentina 14: 3-11.

Martínez, A. 1949. Notas coleopterológicas II. Cambios necesarios en la nominación de algunos géneros de Gymnetini (Coleoptera Scarabaeidae, Cetoniinae). Anales de la Sociedad Científica Argentina 147: 13-15.

Maury, R. C., G. K. Westbrook, P. E. Baker, P. Bouysse, and D. Westercamp. 1990. Geology of the Lesser Antilles [pp. 141-166]. In: The Caribbean Region. The Geology of North America, Volume H (G. Dengo and J. E. Case, editors). The Geological Society of America, Boulder, CO.

Micó, E., W. E. Hall, and B. C. Ratcliffe. 2001. Descriptions of the larvae of Hoplopyga singularis (Gory and Percheron) and Hologymnetis cinerea (Gory and Percheron) with a revised key to the larvae of New World Gymnetini (Coleoptera: Scarabaeidae: Cetoniinae). The Coleopterists Bulletin 55: 205-217.

Micó, E., M. A. Morón, P. Sipek, and E. Galante. 2008. Larval morphology enhances phylogenetic reconstruction in Cetoniidae (Coleoptera: Scarabaeoidea) and allows the interpretation of the evolution of larval feeding habits. Systematic Entomology 33: 128-144.

Mitter, H. 2007. Amithao erici nov. sp. - eine neue Rosenkäferart aus Nicaragua (Coleoptera, Scarabaeidae, Certoniinae). Linzer Biologische Beiträge 39: 519-520.

Morón, M. A., and R. Arce. 2002. Descriptions of the immatures stages of five Mexican species of Gymnetini (Coleoptera: Scarabaeidae: Cetoniinae). Proeedings of the Entomological Society of Washington 104: 1036-1054.

Morón, M. A., and G. Nogueira. 2007. Halffterinetis, nuevo género mexicano de Cetoniicdae (Coleoptera: Scarabaeoide). Monografías 3ercer Milenio M3M (Sociedad Entomológica Aragonesa) 7: $51-61$.

Moser, J. 1905. Neue Cetoniden-Arten. Annales de la Société Entomologique de Belgique 49: 210-216.

Moser, J. 1907. Beitrag zur Kenntnis der Cetoniden. Annales de la Société Entomologique de Belgique 51: 141-151.

Moser, J. 1908. Beitrag zur Kenntnis der Cetoniden. Annales de la Société Entomologique de Belgique 52: 85-96.

Moser, J. 1910. Beitrag zur Kenntnis der Cetoniden. (Col.). VII. Deutsche Entomologische Zeitschrift 1910: 293-301.

Moser, J. 1911a. Beitrag zur Kenntnis der Cetoniden. Annales de la Société Entomologique de Belgique 55: 119-129.
Moser, J. 1911b. Beitrag zur Kenntnis der Cetoniden (Col.) X. Deutsche Entomologische Zeitschrift 1911: 529-547.

Moser, J. 1912. Beitrag zur Kenntnis der Cetoniden (Col.) XI. Deutsche Entomologische Zeitschrift 1912: $560-574$

Moser, J. 1913. Beitrag zur Kenntnis der Cetoniden. XII. Annales de la Société Entomologique de Belgique 57: 155-169.

Moser, J. 1917. Beitrag zur Kenntnis der Cetoniden. (Col.). Deutsche Entomologische Zeitschrift 1917: 1-22.

Moser, J. 1918. Beitrag zur Kenntnis der Cetoniden. (Col.). XVII. Stettiner Entomologische Zeitung 79: 168-190.

Moser, J. 1921. Neue Cetoniden-Arten (Col.). Stettiner Entomologische Zeitung 82: 183-187.

Neervoort van de Poll, J. R. H. 1886a. Note XIX. Novum genus gymnetinorum. Notes from the Leyden Museum 8: 138

Neervoort van de Poll, J. R. H. 1886b. Note XXXIX. Four new Cetoniidae from Central- and South-America. Notes from the Leyden Museum 8: 231-237.

Nonfried, A. F. 1891. Beitrage zur Kenntniss einiger neuen exotischen Coleopterenspezies. Deutsche Entomologische Zeitschrift 1891: 257-276.

Nonfried, A. F. 1894. Beschreibungen neuer Lamellicornier, Buprestiden und Cerambyciden aus Central- und Süd America. Entomologische Nachrichten 20 (8): 113-142.

Olivier, A. G. 1789. Entomologie, ou Histoire Naturelle des Insectes, avec leurs Caractères Génériques et Specifiques, leur Description, leur Synonymie, et leur Figure Enluminée. Coléoptères, Volume 1 [genera separately paged]. Paris, France.

Peck, S. B. 2011. The beetles of Martinique, Lesser Antilles (Insecta: Coleoptera); diversity and distributions. Insecta Mundi 0178: 1-57.

Perbosc, M. 1839. Insectes nouveaux découverts au Mexique. Revue Zoologique 1839: 261-264.

Perty, M. 1830. Delectus Animalium Articulatorum, quae in Itenere per Brasiliam Annis MDCCCXVIIMDCCCXX Jussu et Auspiciis Maximiliani Josephi I. Bavariae Regis Augustissimi Peracto Collegerunt Dr. J. B. de Spix et Dr. C. F. Ph. de Martius. Digessit, Descripsit, Pingenda Curavit Dr. Maximilianus Perty, Praefetus es et Edidit Dr. C. F. Ph. de Martius. Impensis Editoris, Munich, Germany.

Pouillaude, I. 1913. Description de nouvelles espèces du genre Gymnetis MacLeay. Insecta 3: 236-239, 281-283, 371-375, 391-394.

Ratcliffe, B. C. 1978. A review of the genus Argyripa (Coleoptera: Scarabaeidae). Systematic Entomology 3: 371-378.

Ratcliffe, B. C. 2005. A review of the South American genus Hoplopygothrix Schürhoff (Coleoptera: Scarabaeidae: Cetoniinae: Gymnetini). The Coleopterists Bulletin 59: 136-142.

Ratcliffe, B. C. 2010. A review of the Blaesiina (Coleoptera, Scarabaeidae, Cetoniinae, Gymnetini). Zookeys 34: 105-128.

Ratcliffe, B. C. 2011. Hoplopygothrix Schürhoff revisited: A new species and country record for Bolivia (Coleoptera: Scarabaeidae: Cetoniinae: Gymnetini). The Coleopterists Bulletin 65: 63-66. 
Ratcliffe, B. C. 2012. First reported occurrence and description of a new species of Hoplopyga (Coleoptera: Scarabaeidae: Cetoniinae: Gymnetini) from the West Indies. The Coleopterists Bulletin 66: $111-115$.

Ratcliffe, B. C. 2013a. A revision of the Neotropical genus Amithao Thomson, 1878 (Coleoptera: Scarabaeidae: Cetoniinae: Gymnetini). The Coleopterists Bulletin 67: 265-292.

Ratcliffe, B. C. 2013b. A revision of the Neotropical genus Desicasta (Coleoptera: Scarabaeidae: Cetoniinae: Gymnetini). The Coleopterists Bulletin 67: 447-456.

Ratcliffe, B. C. 2014a. A review of the Neotropical genera Badelina Thomson, 1880, Balsameda Thomson, 1880, Guatemalica Neervoort van de Poll, 1886, and Heterocotinis Martínez, 1948 (Coleoptera: Scarabaeidae: Cetoniinae: Gymnetini). The Coleopterists Bulletin 68: 241-262.

Ratcliffe, B. C. 2014b. A review of the Neotropical genera Astroscara Schürhoff, 1937, Chiriquibia Bates, 1889, Hadrosticta Kraatz, 1892, Jansonia Schürhoff, 1937, Macrocranius Schürhoff, 1935, and Tiarocera Burmeister, 1842 (Coleoptera: Scarabaeidae: Cetoniinae: Gymnetini). The Coleopterists Bulletin 68: 363-376.

Ratcliffe, B. C. 2015a. A revision of the Neotropical genus Allorrhina Burmeister, 1842 (Coleoptera: Scarabaeidae: Cetoniinae: Gymnetini). The Coleopterists Bulletin 69: 91-113.

Ratcliffe, B. C. 2015b. A review of the Neotropical genus Marmarina Kirby, 1827 with description of a new species from Argentina (Coleoptera: Scarabaeidae: Cetoniinae: Gymnetini). The Coleopterists Bulletin 69: 183-201.

Ratcliffe, B. C. 2017. The fourteenth Amithao Thomson, 1878: A remarkable new species from Ecuador (Coleoptera: Scarabaeidae: Cetoniinae: Gymnetini). The Coleopterists Bulletin 71: 655-660.

Ratcliffe, B. C. 2018. A monographic revision of the genus Gymnetis MacLeay, 1819 (Coleoptera: Scarabaeidae: Cetoniinae). Bulletin of the University of Nebraska State Museum 31: 1-250.

Ratcliffe, B. C., and C. Deloya. 1992. The biogeography and phylogeny of Hologymnetis (Coleoptera: Scarabaeidae: Cetoniinae) with a revision of the genus. The Coleopterists Bulletin 45: 161-202.

Ratcliffe, B. C., and E. Micó. 2001. A review of the Neotropical genus Neocorvicoana Ratcliffe and Micó, new genus (Coleoptera: Scarabaeidae: Cetoniinae: Gymnetini). The Coleopterists Bulletin 55: 279-296.

Ratcliffe, B. C., and W. B. Warner. 2011. A revision of the genus Gymnetina Casey, 1915 (Coleoptera: Scarabaeidae: Cetoniinae: Gymnetini). Insecta Mundi 0173: 1-28.

Ritsema, C. 1885. Four new species of exotic Coleoptera. Notes from the Leiden Museum 7: 39-46.

Sallé, M. A. 1857. Description d'un Gymnétide provenant des environs de Santa-Fé de Bogota. Annales de la Société Entomologique de France (Series 3) 5: 617-618.

Schaeffer, C. 1905. Some additional new genera and species of Coleoptera found within the limit of the
United States. The Museum of the Brooklyn Institute of Arts and Sciences, Science Bulletin 1: 141-179.

Schaum, H. R. 1841. Analecta Entomologica (Dissertatio Inauguralis). Halle, Germany.

Schaum, H. R. 1844. Observations critiques sur la famille des lamellicornes mélitophiles. Annales de la Société Entomologique de France (Series 2) 2: 333-426.

Schaum, H. R. 1845. Catalogue des espèces-connues qui entrent dans la famille des lamellicornes mélitophiles. Annales de la Société Entomologique de France (Series 2) 3: 37-56.

Schaum, H. R. 1848. Two decades of new Cetoniidae. Transactions of the Royal Entomological Society of London 5: 64-76.

Schaum, H. R. 1849. Observations critiques sur la famille des lamellicornes mélitophiles. $2^{\mathrm{e}}$ Partie (1). Annales de la Société Entomologique de France (Series 2) 7: 241-295.

Schenkling, S. 1921. Coleopterorum Catalogus, pars 72. Scarabaeidae: Cetoniinae. W. Junk, Berlin, Germany.

Schoch, G. 1895. Die Genera und Species meiner CetonidenSammlung. I. Teil: Trib. Goliathidae, Gymnetidae, Madagassae, Schizorrhinidae. Zürcher and Furrer, Zurich, Switzerland.

Schoch, G. 1896a. Einige neue Cetoniden. Entomologische Nachrichten 22: 84-87, 179-181, 328-332.

Schoch, G. 1896b. Nachtrag zu: [sic] Schoch, Genera und Species meiner Cetoniden-Sammlung. Mitteilungen der Schweizerischen Entomologischen Gesellschaft 9: $358-370$.

Schoch, G. 1897. Nachtrag V zu Schoch: Genera und Species meiner Cetoniden-Sammlung. Mitteilungen der Schweizerischen Entomologischen Gesellschaft 10: 37-60.

Schoch, G. 1898. Nachtrag VII zu Schoch: Genera und Species meiner Cetoniden-Sammlung. Mitteilungen der Schweizerischen Entomologischen Gesellschaft 10: 101-119.

Schönherr, C. J. 1817. Synonymia Insectorum oder Versuch einer Synonymie aller bisher bekannten Insekten; nach Fabricii Systema Eleutheratorum etc. geordnet. Volume 1, Part 3. E. Bruzelius, Upsala, Sweden.

Schürhoff, P. N. 1933. Beiträge zur Kenntnis der Cetoniden III. Entomologisches Nachrichtenblatt 7: 89-96.

Schürhoff, P. N. 1935. Beiträge zur Kenntnis der Cetoniden (Col.). VII. Mitteilungen der Deutschen Entomologischen Gesellschaft 6: 21-28.

Schürhoff, P. N. 1937. Beiträge zur Kenntnis der Cetoniden (Col.). VIII. Revision der Gattung Gymnetis MacLeay. Deutsche Entomologische Zeitschrift 1937: $56-80$.

Schürhoff, P. N. 1942. Beiträge zur Kenntnis der Cetoniden (Col.) IX. Mitteilungen der Münchner Entomologischen Gesellschaft 32: 279-293.

Sharp, D. 1877. Description of some new species of beetles (Scarabaediae) from Central America. Journal of the Linnean Society of London, Zoology 13: 129-138.

Shaughney, J. M., and B. C. Ratcliffe. 2015. A monographic revision of the Neotropical genus 
Hoplopyga Thomson (Coleoptera: Scarabaeidae: Cetoniinae: Gymnetini). The Coleopterists Bulletin 69: 579-638.

Strand, E. 1934. Miscellanea nomenclatorica zoologica et palaeontologica. Folia Zoologica et Hydrobiologica 6: 271-277.

Sturm, J. 1826. Catalog meiner Insekten-Sammlung, Erster Theil, Käfer. Published by the Author, Nürnberg, Germany.

Swederus, N. S. 1787. Et nytt genus, och femtio nya species as Insecter, beskrisne. Kungliga Vetenskaps Akademiens nya Handlingar 8: 181-201.

Thomson, J. 1857. Description de quatorze espèces nouvelles. Archives Entomologiques 1: 129-136.

Thomson, J. 1860. Cetonides [pp. 30-38]. Museé Scientifique ou Receuill d'Histoire Naturelle. Published by the author, Paris, France.

Thomson, J. 1878. Typi Cetonidarum suivis de Typi Monommidarum et de Typi Nilionidarum Musaei Thomsoniani. E. Deyrolle, Paris, France.

Thomson, J. 1880. Diagnoses de genres nouveaux de la famille des cétonides. Naturaliste 2: 268-269, 277-278.

Vigors, N. A. 1825. Descriptions of some rare, interesting, or hitherto uncharacterized subjects of zoology. The Zoological Journal 1: 409-418.

Voet, J. E. 1779. Catalogus Systematicus Coleopterorum. Tomus 1. Bakhuysen, The Hague, Netherlands.

Waterhouse, C. O. 1876. Descriptions of two new species of Cetoniidae. Annals and Magazine of Natural History (series 4) 18: 422-423.

Weber, F. 1801. Observationes Entomologiquae, Continentes Novorum quae Condidit Generum Characteres, et Nuper Detectarum Specierum Descriptiones. Impensis Bibliopolii Academici Novi, Kiel, Germany.

Westwood, J. O. 1874. Description of some new species of exotic Cetoniidae. Transactions of the Entomological Society of London 1874: 473-481.

Wheeler, Q. 2004. Taxonomic triage and the poverty of phylogeny. Philosophical Transactions of the Royal Society London B 359: 571-583.

Wheeler, Q. 2013. The Westwood Medal, revisionary taxonomy, and the R.E.S. Antenna 37: 208-209.

Wheeler, Q. D., and N. I. Platnick. 2000. The phylogenetic species concept (sensu Wheeler and Platnick) [p. 55-69]. In: Species Concepts and Phylogenetic Theory. A Debate (Q. D. Wheeler and R. Meier, editors). Columbia University Press, New York, NY.

White, A. 1847. Remarks on some Cetoniadae (sic), with the description of a new Australian species. Annals and Magazine of Natural History (Series 1) 20: 264-267.

Wiedemann, C. R. W. 1824. Munus rectoris in Academia Christiana Albertina aditurus Analecta entomologica ex Museo Regio Havniens: maxime congesta profert iconibusque illustrat. Regio Topographeo Scholarum, Kiel, Germany.

Woodruff, R. E. 2008. The genus Cotinis Burmeister in the eastern United States, with description of a new species from the Florida Keys, including a checklist of the genus (Coleoptera: Scarabaeidae: Cetoniinae). Insecta Mundi 0051: 1-13.

(Received 25 May 2018; accepted 15 December 2018. Publication date 25 March 2019.) 